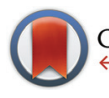

CrossMark

Cite this: Dalton Trans., 2015, 44 955

Received 6th October 2014, Accepted 26th October 2014

DOI: $10.1039 / c 4 d t 03074 \mathrm{e}$

www.rsc.org/dalton

\title{
Synthesis, structure and reactivity study of magnesium amidinato complexes derived from carbodiimides and $N, N^{\prime}$-bis(2,6-diisopropylphenyl)- 1,4-diaza-butadiene ligands $\uparrow$
}

\author{
Srinivas Anga, Jayeeta Bhattacharjee, Adimulam Harinath and Tarun K. Panda*
}

\begin{abstract}
We report an amidinato ligand-supported series of magnesium complexes obtained from the insertion of a magnesium-carbon bond into a carbon-nitrogen double bond of different carbodiimides and $\alpha$-diimine ligands. The magnesium complexes $\left[\mathrm{Mg}\left(\mathrm{CH}_{2} \mathrm{Ph}\right)\left\{\mathrm{CyN}=\mathrm{C}\left(\mathrm{CH}_{2} \mathrm{Ph}\right) \mathrm{NCy}\right\}\right]_{2} \quad(1), \quad\left[\mathrm{Mg}\left(\mathrm{CH}_{2} \mathrm{Ph}\right)\right.$ $\left.\left\{{ }^{\mathrm{P} r N}=\mathrm{C}\left(\mathrm{CH}_{2} \mathrm{Ph}\right) \mathrm{N}^{\mathrm{P} P}\right\}\right]_{2}$ (2) and the homoleptic $\left[\mathrm{Mg}\left\{{ }^{\mathrm{t}} \mathrm{BuN}=\mathrm{C}\left(\mathrm{CH}_{2} \mathrm{Ph}\right) \mathrm{N}^{\mathrm{t}} \mathrm{Bu}\right\}_{2}\right]$ (3) $\left(\mathrm{Cy}=\right.$ cyclohexyl, ${ }^{\mathrm{P}} \mathrm{Pr}=$ isopropyl, ${ }^{t} \mathrm{Bu}=$ tert-butyl) were prepared by the reaction of dibenzyl magnesium $\left[\mathrm{Mg}\left(\mathrm{CH}_{2} \mathrm{Ph}\right)_{2}\left(\mathrm{Et}_{2} \mathrm{O}\right)_{2}\right]$ with the respective carbodiimides either in $1: 1$ or $1: 2$ molar ratio in toluene. The analogous reaction of $\left[\mathrm{Mg}\left(\mathrm{CH}_{2} \mathrm{Ph}\right)_{2}\left(\mathrm{Et}_{2} \mathrm{O}\right)_{2}\right]$ with the $\mathrm{N}, \mathrm{N}^{\prime}$-bis(2,6-diisopropylphenyl)-1,4-diaza-1,3-butadiene (Dipp $2 \mathrm{DAD}$ ) ligand afforded the corresponding homoleptic magnesium complex $\left[\mathrm{Mg}\left\{\mathrm{DippN}=\mathrm{C}\left(\mathrm{CH}_{2} \mathrm{Ph}\right) \mathrm{CH}_{2} \mathrm{NDipp}_{2}\right]\right.$ (4) (Dipp = 2,6 diisopropylphenyl) in good yield. The solid-state structures of magnesium complexes 1-4 were confirmed by single-crystal X-ray diffraction analysis. It was observed that in each case, a magnesium-carbon bond was inserted into the carbon-nitrogen double bond of either carbodiimides or $\mathrm{Dipp}_{2} \mathrm{DAD}$ resulting in a monoanionic amido-imino ligand. In a further reaction between 1 and $\mathrm{N}$-aryliminopyrrolyl ligand 2-(2,6- $\left.{ }^{i} \mathrm{Pr}_{2} \mathrm{C}_{6} \mathrm{H}_{3} \mathrm{~N}=\mathrm{CH}\right) \mathrm{C}_{4} \mathrm{H}_{3} \mathrm{NH}$ (ImpDipp-H) in $1: 2$ molar ratio, a new magnesium complex $\left[\mathrm{Mg}(\mathrm{ImpDipp})_{2}\left\{\mathrm{CyN}=\mathrm{C}\left(\mathrm{CH}_{2} \mathrm{Ph}\right) \mathrm{NHCy}\right\}\right]$ (5), with one amidinato and two aryliminopyrrolyl ligands in the coordination sphere, was obtained in good yield. In contrast, the homoleptic magnesium complex 4 reacted with one equivalent of $\mathrm{N}$-aryliminopyrrolyl ligand (ImpDipp-H) to produce another mixed ligated magnesium complex $\left[\mathrm{Mg}\left\{\mathrm{DippN}=\mathrm{C}\left(\mathrm{CH}_{2} \mathrm{Ph}\right) \mathrm{CH}_{2} \mathrm{NDipp}\right\}(I m p D i p p)\right]$ (6), with a benzylated $\mathrm{DAD}$ ligand and aryliminopyrrolyl ligands in the coordination sphere. Further reaction of complex $\mathbf{4}$ with benzyl alcohol $\left(\mathrm{PhCH}_{2} \mathrm{OH}\right)$ afforded the third mixed ligated magnesium complex $\left[\mathrm{Mg}\left\{\mathrm{DippN}=\mathrm{C}\left(\mathrm{CH}_{2} \mathrm{Ph}\right)\right.\right.$ $\left.\mathrm{CH}_{2} \mathrm{NDipp}\right\}\left(\mathrm{OCH}_{2} \mathrm{Ph}\right)_{2}$ ] (7) in very good yield. The magnesium complexes 5-7 were characterised using standard analytical/spectroscopic techniques and their solid-state structures were established by singlecrystal X-ray diffraction analysis.
\end{abstract}

\section{Introduction}

Even though organomagnesium halides of the type RMgX were discovered in 1900 by Victor Grignard, the relevance of these compounds is significant even today in organic and organometallic synthesis. ${ }^{1}$ Such 'Grignard reagents', which can still be accessed in high yield from the reaction between elemental magnesium and organic halides RX in the presence of ethereal solvents, ${ }^{2}$ have proved to be extremely powerful synthetic tools

Department of Chemistry, Indian Institute of Technology Hyderabad, Ordnance Factory Estate, Yeddumailaram 502205, Telangana, India. E-mail: tpanda@iith.ac.in; Fax: +91 (40) 2301 6032; Tel: +91 (40) 23016036 $\dagger$ Electronic supplementary information (ESI) available. CCDC 1019669-1019675. For ESI and crystallographic data in CIF or other electronic format see DOI: 10.1039/c4dt03074e because of their high reactivity; they allow the nucleophilic introduction of organic groups as carbanion equivalents and for that reason, they belong to the standard repertoires of both organic and organometallic synthesis. Heteroleptic Lewisacidic magnesium alkyl complexes have also been found to be promising catalysts for several polymerisation reactions. ${ }^{3-5}$ The importance of organomagnesium complexes led to extensive investigations of their molecular structures, both in solution and solid state, as well as their physical and chemical properties. Several review articles ${ }^{6-8}$ have described the structural principles of organomagnesium derivatives. Magnesium dialkyls are highly reactive towards diimines, comprehensively showing different reaction pathways depending on the steric bulk of the alkyl ligands and functional groups integrated into the diimine backbone. Magnesium complexes with diimine ligands such as 2,8-bis(tetramethylguanidino)naphthalene, 
1,2-bis(tetra-methyl-guanidino)benzene via neutral coordination have been known. ${ }^{9}$ Bi-radical methyl bridged magnesium complexes such as $\left[\left(\alpha \text {-diimine }{ }^{-\bullet}\right) \mathrm{Mg}^{+}\left(\mu-\mathrm{CH}_{3}\right)\right]_{2}$ obtained from single electron transfer (SET), with a radical anion in its coordination sphere, have also been recently reported by Bailey et al. ${ }^{10}$ In addition, more fascinating $\mathrm{C}$ alkylated and $\mathrm{N}$ alkylated magnesium complexes have also been studied using Lewis acid of p-block $\left(\mathrm{AlMe}_{3}\right)$ or d-block $\left(\mathrm{ZnMe}_{2}\right)$ metal alkyl compounds. In most cases, the alkyl groups migrated from the metal centre to iminic proligands to generate in situ new mono-anionic imido-amido ancillary ligands. ${ }^{11-14}$

Although some earlier reports are available, ${ }^{15}$ recently Anwander and co-workers exploited various alkyl migrations in the permethylated magnesium complex $\mathrm{Mg}\left(\mathrm{AlMe}_{4}\right)_{2}$ with the diimine ligand $\mathrm{PhCH}=\mathrm{NCH}_{2} \mathrm{CH}_{2} \mathrm{~N}=\mathrm{CHPh}$ and dimethyl magnesium $\left(\mathrm{MgMe}_{2}\right)$ with $\mathrm{PhCH}=\mathrm{NCH}_{2} \mathrm{CH}_{2} \mathrm{~N}=\mathrm{CHPh}$, yielding heteroleptic magnesium methyl complexes supported by an imino-amido ligand formed via alkyl migration. ${ }^{16} \mathrm{We}$ also recently reported a group 4 metal-nitrogen bond inserted into a carbon-nitrogen double bond of carbodiimides and $\alpha$-diimines to afford guanidinate and amido-imino ligand supported group 4 metal complexes, respectively. ${ }^{17}$ The ancillary monoanionic guanidinate ligands were formed by the migration of $-\mathrm{NMe}_{2}$ from a transition metal to the carbodiimide backbones. However, analogous reactions of carbodiimides with group 2 metal alkyls have not been reported so far. Thus, we were interested in exploring the potential of different carbodiimides as imino-amido ligands in magnesium alkyl chemistry.

In this context, the synthetic and structural details of magnesium complexes having molecular formulae $\left[\mathrm{Mg}\left(\mathrm{CH}_{2} \mathrm{Ph}\right)\right.$ $\left.\left\{\mathrm{CyN}=\mathrm{C}\left(\mathrm{CH}_{2} \mathrm{Ph}\right) \mathrm{NCy}\right\}\right]_{2} \quad(\mathbf{1}), \quad\left[\mathrm{Mg}\left(\mathrm{CH}_{2} \mathrm{Ph}\right)-\left\{{ }^{\mathrm{i}} \mathrm{PrN}=\mathrm{C}\left(\mathrm{CH}_{2} \mathrm{Ph}\right)-\right.\right.$ $\left.\left.\mathrm{N}^{\mathrm{i}} \mathrm{Pr}\right\}\right]_{2}$ (2), and homoleptic $\left[\mathrm{Mg}\left\{{ }^{t} \mathrm{BuN}=\mathrm{C}-\left(\mathrm{CH}_{2} \mathrm{Ph}\right) \mathrm{N}^{t} \mathrm{Bu}\right\}_{2}\right]$ (3) $\left(\mathrm{Cy}=\right.$ cyclohexyl, ${ }^{\mathrm{i}} \mathrm{Pr}=$ isopropyl, ${ }^{t} \mathrm{Bu}=$ tert-butyl $)$ and $[\mathrm{Mg}$ $\left\{\right.$ DippN $\left.=\mathrm{C}\left(\mathrm{CH}_{2} \mathrm{Ph}\right) \mathrm{CH}_{2} \mathrm{NDipp}_{2}\right]$ (4) are presented. We also report the preparation and molecular structures of three mixed ligand magnesium complexes, $\left[\mathrm{Mg}(\mathrm{ImpDipp})_{2-}\{\mathrm{CyN}=\right.$ $\left.\left.\mathrm{C}\left(\mathrm{CH}_{2} \mathrm{Ph}\right) \mathrm{NHCy}\right\}\right] \quad(5), \quad\left[\mathrm{Mg}\left\{\mathrm{DippN}=\mathrm{C}-\left(\mathrm{CH}_{2} \mathrm{Ph}\right) \mathrm{CH}_{2} \mathrm{NDipp}\right\}-\right.$ (ImpDipp) $]$ (6) and $\left[\mathrm{Mg}\left\{\mathrm{DippN}=\mathrm{C}\left(\mathrm{CH}_{2} \mathrm{Ph}\right)-\mathrm{CH}_{2} \mathrm{NDipp}\right\}\right.$ $\left.\left(\mathrm{OCH}_{2} \mathrm{Ph}\right)_{2}\right]$ (7).

\section{Results and discussion}

\section{Magnesium amidinato complexes}

The magnesium amidinato complexes of compositions $[\mathrm{Mg}$ $\left.\left(\mathrm{CH}_{2} \mathrm{Ph}\right)-\left\{\mathrm{CyN}=\mathrm{C}\left(\mathrm{CH}_{2} \mathrm{Ph}\right) \mathrm{NCy}\right\}\right]_{2} \quad$ (1) and $\left[\mathrm{Mg}\left(\mathrm{CH}_{2} \mathrm{Ph}\right)-\right.$ $\left.\left\{{ }^{\mathrm{i}} \mathrm{PrN}=\mathrm{C}\left(\mathrm{CH}_{2} \mathrm{Ph}\right) \mathrm{N}^{\mathrm{i}} \mathrm{Pr}\right\}\right]_{2}$ (2) were synthesised by the reaction between magnesium dibenzyl etherate complex $[\mathrm{Mg}$ $\left.\left(\mathrm{CH}_{2} \mathrm{Ph}\right)_{2}\left(\mathrm{Et}_{2} \mathrm{O}\right)_{2}\right]$ and either $N, N^{\prime}$-dicyclohexylcarbodiimide (for 1) or $N, N^{\star}$-diisopropylcarbodiimide (for 2 ) at $60{ }^{\circ} \mathrm{C}$ (Scheme 1). Both complexes were obtained as pure forms in good yield through re-crystallisation from hot toluene. The analogous reaction of $\left[\mathrm{Mg}\left(\mathrm{CH}_{2} \mathrm{Ph}\right)_{2}\left(\mathrm{Et}_{2} \mathrm{O}\right)_{2}\right]$ with the more bulky $N, N^{\prime}$-ditert-butylcarbodiimide afforded the corresponding homoleptic

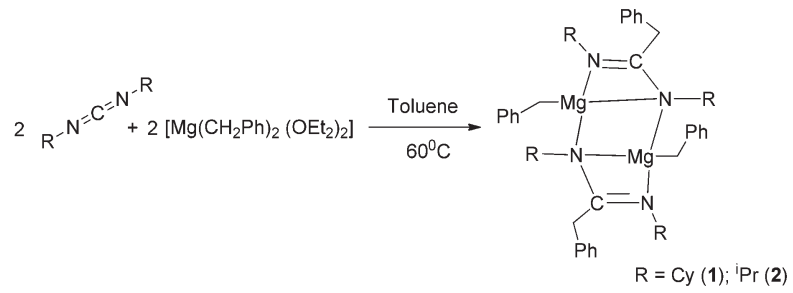

Scheme 1 Synthesis of amidinato magnesium complexes 1 and 2.

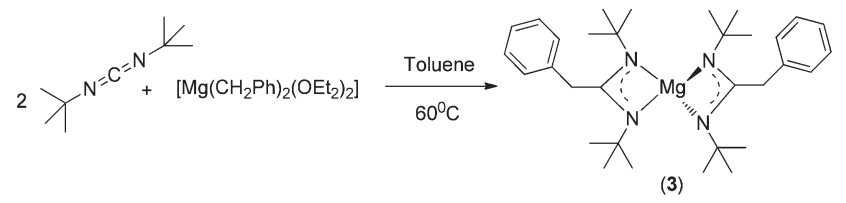

Scheme 2 Synthesis of amidinato magnesium complex 3.

magnesium complex $\quad\left[\mathrm{Mg}\left\{{ }^{t} \mathrm{BuN}=\mathrm{C}\left(\mathrm{CH}_{2} \mathrm{Ph}\right) \mathrm{N}^{t} \mathrm{Bu}\right\}_{2}\right]$

(Scheme 2). The new magnesium complexes 1-3 were characterised using standard analytical and spectroscopic techniques, and the solid-state structures of all three magnesium complexes were established by single-crystal X-ray diffraction analysis.

The ${ }^{1} \mathrm{H}$ NMR spectra measured in $\mathrm{C}_{6} \mathrm{D}_{6}$ of complexes 1 and 2 were similar and exhibited only one set of signals in solution. Each of complexes 1 and 2 showed a sharp singlet at $\delta 1.72$ and $1.89 \mathrm{ppm}$, respectively, for the resonance of two benzylic protons bound to a magnesium ion. These observations are in agreement with the other magnesium benzyl

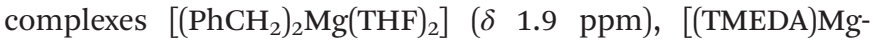

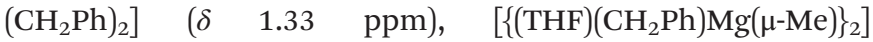
$\left(\begin{array}{lll}\delta & 1.88 & \mathrm{ppm}\end{array}\right)$ and $\left[\mathrm{HC}\left\{\mathrm{C}\left(\mathrm{CH}_{3}\right) \mathrm{NDipp}\right\}_{2} \mathrm{Mg}\left(\mathrm{CH}_{2} \mathrm{Ph}\right)(\mathrm{THF})\right]$ (1.6 ppm) reported by Bailey et al. ${ }^{18}$ The singlet resonance that appeared at $\delta 3.70$ (for complex 1) and $3.40 \mathrm{ppm}$ (for complex 2) can be assigned to benzylic protons attached to the carbon atom of amidinato ligands. The multiplets for cyclohexyl moieties attached to the nitrogen atoms were in the expected region for complex 1. For complex 2, multiplets at $\delta 3.52-3.47 \mathrm{ppm}$ can be assigned to two non-equivalent isopropyl- $\mathrm{CH}$ protons which are not well resolved on the NMR time scale. In addition, two doublets were observed at $1.13 \mathrm{ppm}$ and $1.10 \mathrm{ppm}$ for the chemically non-equivalent isopropyl methyl protons $-\mathrm{CHMe}_{2}$. In ${ }^{13} \mathrm{C}\left\{{ }^{1} \mathrm{H}\right\}$ NMR spectra of complexes 1 and 2, the signals at $\delta 173.7$ and $173.5 \mathrm{ppm}$ respectively indicate the presence of $\mathrm{sp}^{2}$ carbon $\left(-\mathrm{N}-\mathrm{C}\left(\mathrm{CH}_{2} \mathrm{Ph}\right)=\mathrm{N}-\right)$ in the solution. In the ${ }^{1} \mathrm{H}$ NMR spectra of homoleptic magnesium complex $\mathbf{3}$, the sharp singlet at $3.71 \mathrm{ppm}$ corresponds to the resonance of four benzylic protons of $-\mathrm{CH}_{2} \mathrm{Ph}$ groups attached to the amidinato ligand backbone whereas the other sharp singlet at $\delta$ 1.01 ppm can be assigned to the 36 methyl protons $\mathrm{CH}_{3}$ present in four tert-butyl groups. We also observed a resonance signal at $\delta 173.5 \mathrm{ppm}$ for $\left(-\mathrm{N}-\mathrm{C}\left(\mathrm{CH}_{2} \mathrm{Ph}\right)=\mathrm{N}-\right)$ carbon in the ${ }^{13} \mathrm{C}\left\{{ }^{1} \mathrm{H}\right\}$ NMR spectra of 3 which corresponds to those for complexes 1 and 2 . 
1: Mg1-N1 2.1012(16), Mg1-N2 2.2054(14), Mg1-C19 2.1399(17), Mg1-N2 ${ }^{\mathrm{i}}$ 2.1420(14), N1-C1 1.3125(18), N2-C1 1.3753(18), N1-C7 1.4749(17), N2-C13 1.4831(18), C1-C28 1.515(2), N1-Mg1-C19 123.96(6), N1-Mg1-N2 ${ }^{\mathrm{i}}$ 107.10(5), C19Mg1-N2 ${ }^{\mathrm{i}} \quad 122.68(6), \quad \mathrm{N} 1-\mathrm{Mg} 1-\mathrm{N} 2 \quad 63.35(5), \quad \mathrm{C} 19-\mathrm{Mg} 1-\mathrm{N} 2$ 126.99(6), N2 ${ }^{\mathrm{i}}-\mathrm{Mg} 1-\mathrm{N} 2$ 96.77(5), C1-N1-Mg1 91.81(9), C7-N1Mg1 143.29(10), C1-N2-C13 118.37(11), C1-N2-Mg1 ${ }^{\mathrm{i}}$ 117.02(9), C13-N2-Mg1 ${ }^{\mathrm{i}}$ 113.28(9), C1-N2-Mg1 85.81(9), C13N2-Mg1 133.84(9), $\quad \mathrm{Mg}^{\mathrm{i}}{ }^{\mathrm{i}} \mathrm{-N} 2-\mathrm{Mg} 1 \quad 83.23(5), \quad \mathrm{N} 1-\mathrm{C} 1-\mathrm{N} 2$ 114.70(12), C1-N1-C7 121.14(12).

2: $\mathrm{Mg} 1-\mathrm{N} 1 \quad 2.0980(10), \quad \mathrm{Mg} 1-\mathrm{N} 2 \quad 2.1922(10), \quad \mathrm{Mg} 1-\mathrm{N} 2^{\mathrm{i}}$ 2.1395(11), Mg1-C15 2.1509(13), N1-C1 1.3079(13), N2-C1 1.3815(13), N2-Mg1 ${ }^{\mathrm{i}}$ 2.1395(11), C1-C8 1.5201(13), N1-Mg1N2 63.69(3), N1-Mg1-N2 ${ }^{\mathrm{i}}$ 107.67(4), N1-Mg1-C15 125.41(5), N2 ${ }^{\mathrm{i}}-\mathrm{Mg} 1-\mathrm{C} 15$ 121.59(4), N2 ${ }^{\mathrm{i}}-\mathrm{Mg} 1-\mathrm{N} 2$ 94.09(4), C15-Mg1-N2 128.44(5), C1-N1-Mg1 93.12(6), C5-N1-Mg1 142.88(7), C1-N2$\mathrm{Mg}_{1}{ }^{\mathrm{i}}$ 114.15(7), C2-N2-Mg1 ${ }^{\mathrm{i}}$ 114.19(6), C1-N2-Mg1 87.14(6), $\mathrm{Mg} 1^{\mathrm{i}}-\mathrm{N} 2-\mathrm{Mg} 1 \quad 85.91(4) . \quad \mathrm{N} 1-\mathrm{C} 1-\mathrm{N} 2 \quad 114.72(8), \quad \mathrm{N} 1-\mathrm{C} 1-\mathrm{C} 8$ 123.98(9), N2-C1-C8 121.27(9).

Although there is ongoing interest in magnesium organometallics ${ }^{19}$ and particularly in the amido and amidinato-metal chemistry of magnesium, ${ }^{20,21}$ complexes 1-3 represent a series of various heteroleptic and homoleptic magnesium complexes containing amidinato ligands derived from three different carbodiimides. Therefore, their molecular structures in the solid state were determined by X-ray diffraction analysis. Complexes 1 and 2 crystallised in the monoclinic space group $P 2_{1} / c$, having two and four molecules of 1 and 2 respectively in their unit cells. In contrast, complex 3 crystallised in the orthorhombic space group $\mathrm{Pbca}$, having eight individual molecules in the unit cell. The details of their structural parameters are given in Table TS1 in the ESI. $\dagger$ The solid-state structures of complexes 1 and 2 are shown in Fig. $1 \mathrm{a}$ and 1b, respectively, and Fig. 2 represents the molecular structure of complex 3 . Both the centro-symmetric complexes $\mathbf{1}$ and $\mathbf{2}$ are heteroleptic and dimeric in nature. In each case, one of the benzyl groups $\left(\mathrm{CH}_{2} \mathrm{Ph}\right)$ of $\left[\mathrm{Mg}\left(\mathrm{CH}_{2} \mathrm{Ph}\right)_{2}\left(\mathrm{Et}_{2} \mathrm{O}\right)_{2}\right]$ underwent nucleophilic addition at the carbodiimide $\mathrm{sp}$ carbon atom to generate a monoanionic amidinato ligand $\left[\mathrm{RN}=\mathrm{C}\left(\mathrm{CH}_{2} \mathrm{Ph}\right) \mathrm{NR}\right]^{-}[\mathrm{R}=\mathrm{Cy}$ (1) and iPr (2)] moiety. Such migration reactions are known in the literature. ${ }^{14}$ The coordination polyhedra for complexes 1 and $\mathbf{2}$ are formed by the newly formed amidinato ligand moiety through the coordination of imine and amido nitrogen atoms and the benzyl group. In the molecular structures of complexes 1 and 2 two kinds of $\mathrm{Mg}-\mathrm{N}$ distances [2.101(16) and 2.205(14) A for complex 1 and 2.098(10) and 2.192(10) $\AA$ for complex 2] were observed, indicating one short (from amido nitrogen) and one long (from imine nitrogen) attachment to the magnesium atom. ${ }^{20 g}$ These observations were also reflected in the $\mathrm{C}-\mathrm{N}$ bond distances within the ligand moiety (C1-N1 1.313(18) and C1-N2 1.375(18) $\AA$ for complex 1 and C1-N1 1.308 (13) and N2-C1 1.382(13) $\AA$ for 2). Thus, the short-long bonds within the ligand $\left[\mathrm{RN}=\mathrm{C}\left(\mathrm{CH}_{2} \mathrm{Ph}\right) \mathrm{NR}\right]^{-}$indicate the modified nature of the carbodiimide ligand $(\mathrm{RN}=\mathrm{C}=\mathrm{NR})$ where identical $\mathrm{C}-\mathrm{N}$ bonds were observed. The imine nitrogen atom was chelated to the second magnesium
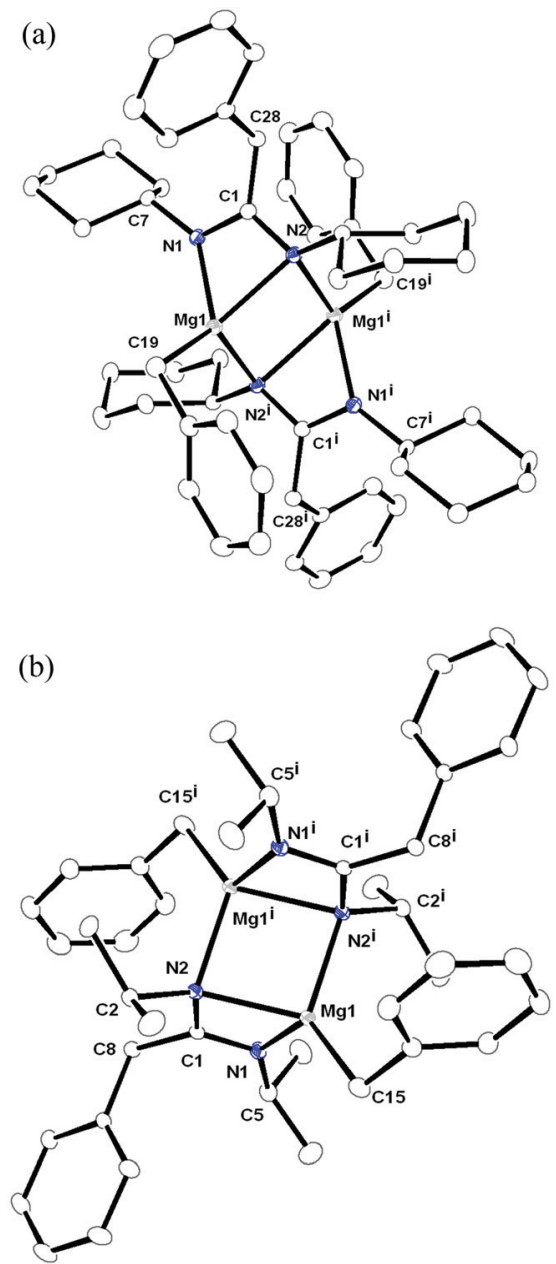

Fig. 1 (a) and (b). Solid-state structures of complexes 1 (a) and 2 (b) and ellipsoids are drawn to encompass $30 \%$ probability. Hydrogen atoms are omitted for clarity. Selected bond lengths $[\AA ̊]$ and bond angles $\left[{ }^{\circ}\right]$.

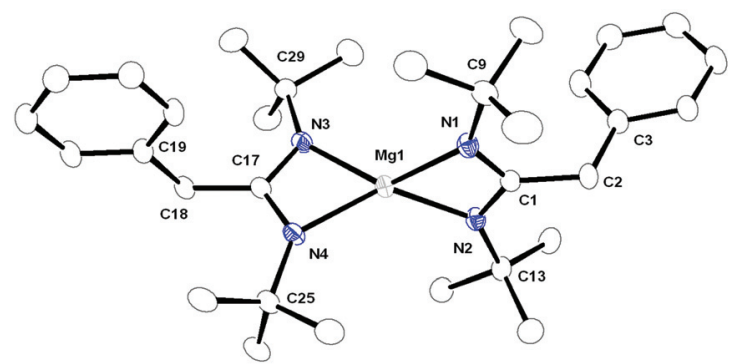

Fig. 2 Solid-state structure of complex 3 and ellipsoids are drawn to encompass $30 \%$ probability. Hydrogen atoms are omitted for clarity. Selected bond lengths [Å] and bond angles [ $\left.{ }^{\circ}\right]$ : Mg1-N1 2.052(4), Mg1N2 2.044(4), Mg1-N3 2.055(4), Mg1-N4 2.044(3), N1-C1 1.347(5), N2C1 1.349(5), N3-C17 1.334(5), N4-C17 1.345(5), C1-C2 1.523(5), C17C18 1.519(5), N2-Mg1-N1 65.96(14), N4-Mg1-N3 65.73(14), N4-Mg1N1 137.35(15), N4-Mg1-N2 134.18(15), N2-Mg1-N3 136.22(15), N1Mg1-N3 131.51(15), C1-N1-Mg1 91.1(2), C1-N2-Mg1 91.4(2), C17-N3Mg1 90.9(2), C17-N4-Mg1 91.1(2), N1-C1-N2 111.5(3), N1-C1-C2 124.1(4), N2-C1-C2 124.3(4), N3-C17-N4 112.2(3), N3-C17-C18 124.5(4), N4-C17-C18 123.1(3). 
atom making the overall structure a dimer. The interactions between $\mathrm{sp}^{2}$ carbon atoms and the magnesium atom could be ignored as the bond distances (2.512 $\AA$ for complex 1 and $2.532 \AA$ for complex 2) are larger. In each case three fourmembered metallacycles $\mathrm{N} 1-\mathrm{C} 1-\mathrm{N} 2-\mathrm{Mg} 1, \mathrm{Mg} 1-\mathrm{N} 2-\mathrm{Mg} 1^{\mathrm{i}}-\mathrm{N} 2^{\mathrm{i}}$ and $\mathrm{N} 1{ }^{\mathrm{i}}-\mathrm{C} 1^{\mathrm{i}}-\mathrm{N} 2^{\mathrm{i}}-\mathrm{Mg} 1^{\mathrm{i}}$ were formed. In $\mathbf{1}$, the planes containing $\mathrm{N} 1, \mathrm{C} 1, \mathrm{~N} 2, \mathrm{Mg} 1$ and $\mathrm{N} 1^{\mathrm{i}}, \mathrm{C} 1^{\mathrm{i}}, \mathrm{N} 2^{\mathrm{i}}, \mathrm{Mg} 1^{\mathrm{i}}$ atoms were parallel and made a dihedral angle of $71.50^{\circ}\left(70.72^{\circ}\right.$ for complex 2) with the plane having $\mathrm{Mg} 1, \mathrm{~N} 2, \mathrm{Mg}^{\mathrm{i}}, \mathrm{N} 2^{\mathrm{i}}$ atoms. The magnesium benzylic carbon distances [2.140(17) for complex 1 and 2.151(13) A for complex 2] were in agreement with the magnesium-carbon alkyl bonds [2.167(2) $\AA$ for [(TMEDA)Mg$\left.\left(\mathrm{CH}_{2} \mathrm{Ph}\right)_{2}\right]^{18}$ and analogous complexes [(2.124(3) and 2.152(6) $\AA]$ reported in the literature. ${ }^{22}$ The geometry of each magnesium ion can be best described as a distorted tetrahedral, which is quite well known in magnesium chemistry.

Complex 3 is homoleptic and monomeric in nature. The deviation from heteroleptic complexes $\mathbf{1}$ and $\mathbf{2}$ can be attributed to the higher reactivity of the corresponding heteroleptic complex $\left[\mathrm{Mg}\left(\mathrm{CH}_{2} \mathrm{Ph}\right)-\left\{{ }^{t} \mathrm{BuN}=\mathrm{C}\left(\mathrm{CH}_{2} \mathrm{Ph}\right) \mathrm{NBu}^{t}\right\}\right]$, which we were unable to isolate after several attempts. As with complexes 1 and 2 , both the magnesium-benzyl bonds were inserted into two carbodiimide carbon-nitrogen bonds to generate two amidinato $\left[{ }^{t} \mathrm{BuNC}\left(\mathrm{CH}_{2} \mathrm{Ph}\right) \mathrm{NBu}^{t}\right]^{-}$moieties, which coordinated to the magnesium atom through all the nitrogen atoms present in the ligand. Unlike in complexes $\mathbf{1}$ and 2, no sequences of short and long $\mathrm{Mg}-\mathrm{N}$ distances were observed; instead all $\mathrm{Mg}-\mathrm{N}$ distances [Mg1-N1 2.052(4), Mg1-N2 2.044(4), Mg1-N3 2.055(4), Mg1-N4 2.044(3)] were in the same range indicating complete delocalisation of the anionic charge over the $\mathrm{N}-\mathrm{C}-\mathrm{N}$ skeleton. This is further confirmed by the similar C-N bond distances [N1-C1 1.347(5), N2-C1 1.349(5), N3-C17 1.334(5), N4-C17 1.345(5)] observed in two [ ${ }^{t} \mathrm{BuNC}-$ $\left.\left(\mathrm{CH}_{2} \mathrm{Ph}\right) \mathrm{NBu}^{t}\right]^{-}$moieties. The $\mathrm{Mg}-\mathrm{C} 1$ (2.468 $\left.\mathrm{A}\right)$ and $\mathrm{Mg} 1-\mathrm{C} 17$ $(2.478 \AA)$ distances were slightly shorter than those in complexes 1 and 2 but long enough to consider any interaction between magnesium and $\mathrm{sp}^{2}$ carbon atoms as present in the $\left[{ }^{t} \mathrm{BuNC}\left(\mathrm{CH}_{2} \mathrm{Ph}\right) \mathrm{NBu}^{t}\right]^{-}$ligand. Two four-membered magnesium metallacycles N1-C1-N2-Mg1 and N3-C17-N4-Mg1 were formed due to bidentate chelation of two amidinato ligands. The plane containing N1, C1, N2, Mg1 atoms was almost orthogonal $\left(85.22^{\circ}\right)$ with the plane having N3, C17, N4, Mg1 atoms. As a result, the two benzyl planes were also near to orthogonal $\left(80.11^{\circ}\right)$ orientation. The geometry around the magnesium atom can be concluded as pseudo-tetrahedral, corresponding to that observed in complexes $\mathbf{1}$ and 2 .

\section{$\left[\mathrm{Mg}\left\{\text { DippN }=\mathrm{C}\left(\mathrm{CH}_{2} \mathrm{Ph}\right) \mathrm{CH}_{2} \mathrm{NDipp}\right\}_{2}\right]$ complex}

$\alpha$-Diimine ligand 1,4-disubstituted diazabutadienes (DAD) have been proved to be an important class of ligands in both fundamental and applied research due to their diversity in coordination and redox properties. ${ }^{23}$ The neutral DAD molecule includes two lone pairs of electrons of nitrogen atoms and $\pi$-electrons of the multiple imine $(\mathrm{N}-\mathrm{C})$ bonds and this molecule can act both as the $\sigma$ - and $\pi$-donor and coordinates to the metal atom as a neutral ligand. ${ }^{24}$ Although dianionic
DAD ligands preferentially coordinate to early transition metals and alkaline earth metals in $\sigma^{2}$ - and $\sigma^{2}, \pi$-coordination modes, ${ }^{25-27}$ in many cases the DAD ligands coordinate to group 3 metal atoms as a $\sigma^{2}$-monoanion, ${ }^{28}$ and in addition, both monoanionic and dianionic coordination modes have been observed for alkaline-earth metal group 12 and group 13 metal complexes. ${ }^{29,30}$ To gain more insight into the structure-reactivity relationships of magnesium DAD complexes, we were interested in studying this chemistry further.

The homoleptic mono-benzylated magnesium complex $\left[\mathrm{Mg}\left\{\text { DippN }=\mathrm{C}\left(\mathrm{CH}_{2} \mathrm{Ph}\right)-\mathrm{CH}_{2} \mathrm{NDipp}\right\}_{2}\right]$ (4) was isolated in good yield by treating $\left[\mathrm{Mg}\left(\mathrm{CH}_{2} \mathrm{Ph}\right)_{2}\left(\mathrm{Et}_{2} \mathrm{O}\right)_{2}\right]$ with the neutral $N, N^{\prime}$-bis(2,6-diisopropyl-phenyl)-1,4-diaza-1,3-butadiene (Dipp $\left.{ }_{2} \mathrm{DAD}\right)$ ligand in toluene at room temperature (Scheme 3). The magnesium complex 4 is a product of the monobenzylation of one of two $\mathrm{C}=\mathrm{N}$ bonds followed by intramolecular hydrogen transfer. Similar reactions have been observed in the reactions of $\mathrm{M}\left(\mathrm{CH}_{2} \mathrm{Ph}\right)_{4}(\mathrm{M}=\mathrm{Zr}$, Hf $)$ with $\alpha$-diimine ligands, with a 2,6-disubstituted aryl ring. ${ }^{14}$ The complex was crystallised from hot toluene as red crystals. Complex 4 was soluble in toluene and THF but insoluble in hexane and pentane. Complex 4 was characterised by ${ }^{1} \mathrm{H},{ }^{13} \mathrm{C}\{1 \mathrm{H}\}$ NMR spectroscopy and combustion analysis, and the molecular structure was established by single-crystal X-ray diffraction analysis. In the ${ }^{1} \mathrm{H}$ NMR spectrum of complex 4 measured in $\mathrm{C}_{6} \mathrm{D}_{6}$, one set of signals was observed. A sharp singlet was observed at $\delta 4.32 \mathrm{ppm}$, which can be assigned to the methylene protons $\left(-\mathrm{CH}_{2}\right)$ of the $\left[\right.$ DippN $\left.=\mathrm{C}\left(\mathrm{CH}_{2} \mathrm{Ph}\right) \mathrm{CH}_{2} \mathrm{NDipp}\right]$ ligand backbone. Two distinct septet signals at $\delta 3.56$ and 2.90 ppm and two doublet resonances having a coupling constant of $6.8 \mathrm{~Hz}$ each appeared at $\delta 1.23$ and $1.13 \mathrm{ppm}$, respectively, due to the $-\mathrm{CH}$ hydrogen and isopropyl methyl hydrogen atoms of the ligand $\left[\text { DippN }=\mathrm{C}\left(\mathrm{CH}_{2} \mathrm{Ph}\right) \mathrm{CH}_{2} \mathrm{NDipp}\right]^{-}$. Additionally, resonance of benzylic protons was observed at $\delta 3.22 \mathrm{ppm}$, which is slightly high-field shifted to the corresponding values of complexes 1-3 ( $\delta$ 3.70, 3.40 and $3.71 \mathrm{ppm}$ respectively). In the ${ }^{13} \mathrm{C}\left\{{ }^{1} \mathrm{H}\right\}$ spectra, resonance at $\delta 173.5$ can be assigned to the imine carbon $\left(-\mathrm{N}=\mathrm{C}\left(\mathrm{CH}_{2} \mathrm{Ph}\right)-\right)$ present in the $\left[\mathrm{DippN}=\mathrm{C}\left(\mathrm{CH}_{2} \mathrm{Ph}\right)-\right.$ $\left.\mathrm{CH}_{2} \mathrm{NDipp}\right]^{-}$moiety. Other signals in ${ }^{13} \mathrm{C}\left\{{ }^{1} \mathrm{H}\right\}$ NMR spectra were in the expected range and in agreement with those of complexes 1-3.

Complex 4 crystallised in the monoclinic space group $C 2 / c$, with four molecules of complex $\mathbf{4}$ and one toluene molecule as the solvent in the unit cell. The details of structural parameters are given in Table TS1 in the ESI $\dagger$ and the solid-state structure of complex 4 is shown in Fig. 3. Complex 4 is monomeric and the coordination polyhedron is formed by the chela-
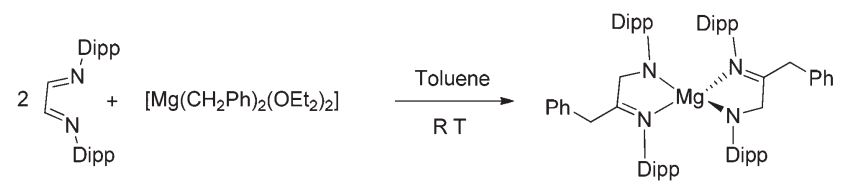

(4)

Scheme 3 Synthesis of magnesium complex 4. 


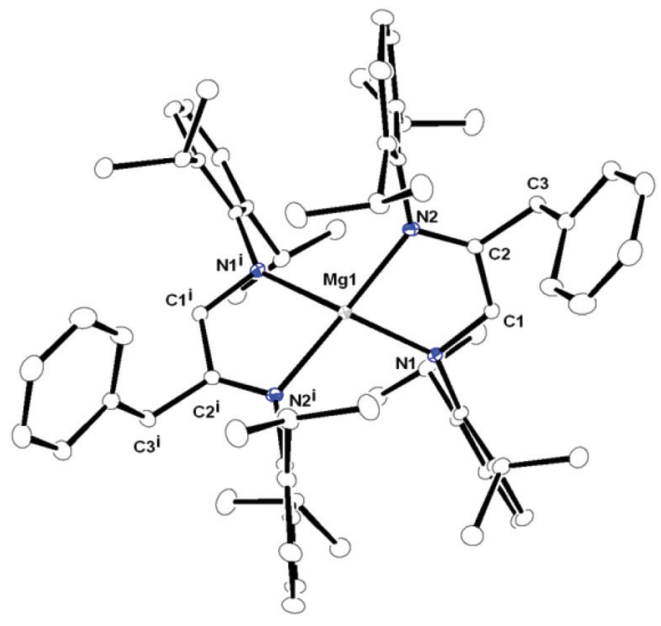

Fig. 3 Solid-state structure of complex 4 and ellipsoids are drawn to encompass $30 \%$ probability. Hydrogen atoms are omitted for clarity. Selected bond lengths [Å] and bond angles [ $\left.{ }^{\circ}\right]$ : Mg1-N1 2.0079(9), Mg1N2 2.2079(10), Mg1-N1 $1^{i}$ 2.0079(9), Mg1-N2 ${ }^{i}$ 2.2079(10), N1-C1 1.4422(12), N2-C2 1.2915(13), C1-C2 1.4919(13), C2-C3 1.5151(14), N1-Mg1-N2 81.54(3), N1-Mg1-N1' 153.44(6), N1-Mg1-N2' 107.39(3), $\mathrm{N} 1^{i}-\mathrm{Mg} 1-\mathrm{N} 2{ }^{\mathrm{i}}$ 81.54(3), N1'-Mg1-N2 107.39(3), N2i-Mg1-N2 141.43(5), C22-N1-Mg1 139.13(6), C1-N1-Mg1 112.82(6), C2-N2-Mg1 110.08(6), C10-N2-Mg1 133.34(6), C22-N1-C1 107.73(7), N2-C2-C1 119.23(9), C2-N2-C10 116.50(8), N2- C2-C3 125.66(9).

tion of one amido and one imine nitrogen atom from each monoanionic [DippN $=\mathrm{C}\left(\mathrm{CH}_{2} \mathrm{Ph}\right) \mathrm{CH}_{2} \mathrm{NDipp}^{-}$ligand moiety formed by the monobenzylation of the DAD ligand. The geometry around the magnesium ion can be best described as a distorted tetrahedral, similar to that of complexes 1-3. Like complexes 1 and 2, two kinds of $\mathrm{Mg}-\mathrm{N}$ distances 2.008(9) and 2.208(1) Å were observed in complex 4, which indicate the presence of amido (short Mg1-N1 bond) and imino (long Mg-N2 bond) nitrogen linkages to the central magnesium ion. As a consequence, C-N bond distances of C1-N1 1.442(12), C1-C2 1.492(13) and C2-N2 1.292(13) ^ within the benzylated DAD moiety were observed. ${ }^{14}$ Thus, the longer $\mathrm{C} 1-\mathrm{N} 1$ and shorter $\mathrm{C} 2-\mathrm{N} 2$ bonds can be assigned to the $\mathrm{C}-\mathrm{N}$ single and double bonds, respectively, whereas the $\mathrm{C} 1-\mathrm{C} 2$ bond is in agreement with only the $\mathrm{C}-\mathrm{C}$ single bond. Two magnesium metallacycles $\mathrm{Mg} 1-\mathrm{N} 1-\mathrm{C} 1-\mathrm{C} 2-\mathrm{N} 2$ and $\mathrm{Mg} 1^{\mathrm{i}}-\mathrm{N} 1^{\mathrm{i}}-\mathrm{C} 1^{\mathrm{i}}-\mathrm{C} 2^{\mathrm{i}}-\mathrm{N} 2^{\mathrm{i}}$ were formed and a dihedral angle of $53.61^{\circ}$ was observed between the planes containing $\mathrm{Mg} 1-\mathrm{N} 1, \mathrm{C} 1, \mathrm{C} 2, \mathrm{~N} 2$ and $\mathrm{Mg} 1^{\mathrm{i}}, \mathrm{N} 1^{\mathrm{i}}, \mathrm{C}^{\mathrm{i}}, \mathrm{C}_{2}{ }^{\mathrm{i}}$, $\mathrm{N} 2^{\mathrm{i}}$ atoms. The bite angle $\mathrm{N} 1-\mathrm{Mg}-\mathrm{N} 2$ of $81.54^{\circ}$ was significantly larger than those in complexes 1-3 $\left(63.5^{\circ}\right.$ for complex $\mathbf{1}$, $63.69^{\circ}$ for complex 2 and $65.96^{\circ}$ for complex 3), which can be explained as the effect of a five-membered magnesocycle formation in complex 4 compared to a four-membered one in complexes 1-3.

\section{Reaction with $\mathrm{N}$-aryliminopyrrole}

When the toluene solution of complex 1 was treated with the $N$-aryl iminopyrrole ligand (ImpDipp-H) in $1: 2$ molar ratio at $60^{\circ} \mathrm{C}$, a penta-coordinated magnesium complex 5 , with benzylated carbodiimide and two iminopyrrolyl ligands was isolated
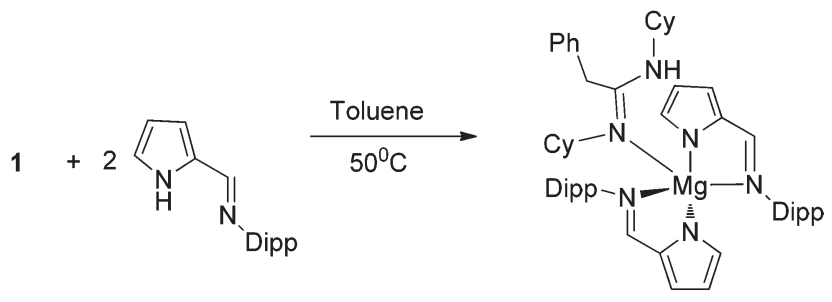

(5)

Scheme 4 Synthesis of magnesium complex 5.

in good yield (Scheme 4). In the ${ }^{1} \mathrm{H}$ NMR spectra of complex $\mathbf{5}$, the broad resonance signal at $\delta 4.06 \mathrm{ppm}$ can be assigned to the amine nitrogen, which is formed after the protonation of the benzylated $N, N$ dicyclocarbodiimide moiety. A singlet peak at $\delta 3.48 \mathrm{ppm}$ indicates the resonance of two benzylic protons of the $\left[\mathrm{CyN}=\mathrm{C}\left(\mathrm{CH}_{2} \mathrm{Ph}\right) \mathrm{NHCy}\right]$ moiety, which is slightly highfield shifted from the corresponding value in complex 1 . The resonances of the two imine (DippN $=\mathrm{CH}-$ ) protons from two iminopyrrolyl ligands appeared as two singlets at $\delta 7.91$ and $7.87 \mathrm{ppm}$. The resonance of the cyclohexyl protons was in the expected range and similar to those in complex 1. A septet signal centred at $\delta 3.34 \mathrm{ppm}$ and one doublet at $1.18 \mathrm{ppm}$, having a coupling constant of $6.4 \mathrm{~Hz}$, are due to the resonance of four $-\mathrm{CH}$ protons and 24 methyl protons, respectively, of the diisopropylphenyl (Dipp) groups present in the iminopyrrolyl ligands. In the ${ }^{13} \mathrm{C}\left\{{ }^{1} \mathrm{H}\right\}$ NMR spectra, signals at 173.5 and $143.4 \mathrm{ppm}$ can be assigned to the carbon atoms present in the $-\mathrm{N}=\mathrm{C}-\mathrm{N}$ and $\mathrm{ImpN}=\mathrm{C}$ groups, respectively. It was noted that the amido nitrogen and the magnesium-bound benzyl group in complex 1 undergo protonations in the presence of two equivalents of iminopyrrole ligands to afford complex $\mathbf{5}$ due to a higher stabilisation of the aromatic pyrrolyl moieties. As a result, $\mathrm{Mg}-\mathrm{N}$ (amido) and $\mathrm{Mg}-\mathrm{C}$ bonds in 1 cleaved to form two new amido and two imino $\mathrm{Mg}-\mathrm{N}$ covalent bonds to stabilise complex 5.

X-ray quality crystals were obtained from hot toluene and the solid-state structure of complex $\mathbf{5}$ was established by single-crystal X-ray diffraction analysis. Heteroleptic magnesium complex $\mathbf{5}$ crystallised in the triclinic space group $P \overline{1}$, with two molecules in the unit cell. The details of structural parameters are given in Table TS1 in the ESI $\uparrow$ and the solidstate structure of complex $\mathbf{5}$ is shown in Fig. 4. The metal centre of the magnesium complex $\mathbf{5}$ was coordinated to two chelating iminopyrrolyl ligands and one imine nitrogen atom from the benzylated carbodiimide ligand $\left[\mathrm{CyN}=\mathrm{C}\left(\mathrm{CH}_{2} \mathrm{Ph}\right)\right.$ $\mathrm{NHCy}$, adopting a five-coordinated distorted square bipyramidal geometry. Four nitrogen atoms N1, N2, N3 and N4, of two iminopyrrolyl ligands constructed the basal plane of the square pyramid and the imine nitrogen N5 from the $\left[\mathrm{CyN}=\mathrm{C}\left(\mathrm{CH}_{2} \mathrm{Ph}\right) \mathrm{NHCy}\right]$ moiety was located at the axial position. The magnesium atom was located $0.70 \AA$ above the basal plane containing the N1, N2, N3 and N4 atoms. The two chelating iminopyrrolyl moieties of 5 were not coplanar and had a dihedral angle of $47.60^{\circ}$ due to the more bulky aromatic sub- 


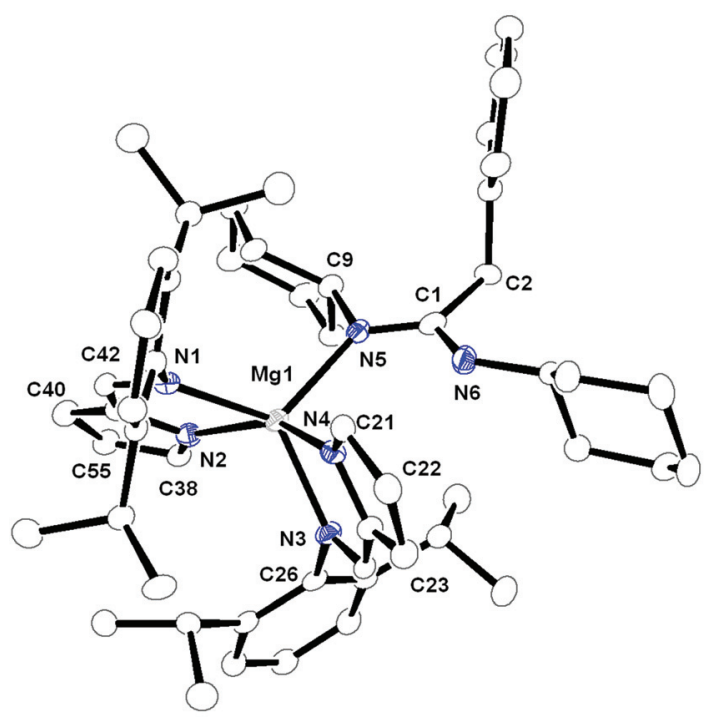

Fig. 4 Solid-state structure of complex 5 and ellipsoids are drawn to encompass $30 \%$ probability. Hydrogen atoms are omitted for clarity. Selected bond lengths [Å] and bond angles [']: Mg1-N1 2.196(3), Mg1N2 2.157(4), Mg1-N3 2.174(4), Mg1-N4 2.166(3), Mg1-N5 2.215(4), N5C1 1.311(5), N5-C9 1.492(5), N6-C1 1.350(5), N2-Mg1-N1 77.45(13), N3-Mg1-N4 77.64(14), N2-Mg1-N4 151.34(14), N2-Mg1-N3 92.70(14), N4-Mg1-N1 89.56(13), N3-Mg1-N1 133.21(14), N2-Mg1-N5 106.96 (14), N4-Mg1-N5 101.67(13), N3-Mg1-N5 106.56(14), N1-Mg1-N5 120.13(14), C42-N1-C43 120.0(3), C42-N1-Mg1 111.9(3), C25-N3-Mg1 112.6(3), C26-N3-Mg1 128.8(3), C21-N4-Mg1 143.4(3) C24-N4-Mg1 111.6(3), C1-N5-Mg1 125.9(3), C9-N5-Mg1 117.6(2), C1-N5-C9 115.8 (3).

stituent 2,6-diisopropylphenyl group on the imine nitrogen atom. The bond distances of $\mathrm{Mg}-\mathrm{N}^{\mathrm{pyr}}[\mathrm{Mg} 1-\mathrm{N} 2$ 2.157(4) $\AA$; $\mathrm{Mg} 1-\mathrm{N} 4,2.166(3) \AA]$ were shorter than those of $\mathrm{Mg}-\mathrm{N}^{\text {imine }}$

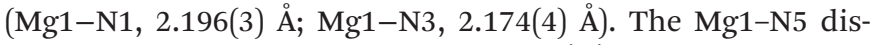
tance of 2.215(4) $\AA$ also fell in the $\mathrm{Mg}-\mathrm{N}^{\text {imine }}$ range. Thus, two six-membered magnesium metallacycles Mg1-N1-C42-C41N4 and Mg1-N3-C25-C24 were formed due to the ligation of two iminopyrrolyl ligands to the magnesium atom. Similar coordination spheres in magnesium chemistry have been reported by us ${ }^{31}$ and others. ${ }^{6-10,21,22}$

A tetra-coordinated magnesium complex $\mathbf{6}$, with mixed iminopyrrolyl and benzylated DAD ligands in the magnesium coordination sphere, was isolated in good yield (Scheme 5) from an analogous reaction between complex $\mathbf{4}$ and [ImpDippH] in 1:1 molar ratio at room temperature. In the ${ }^{1} \mathrm{H}$ proton NMR spectra of complex 6 , the resonance of the one imine (DippN $=\mathrm{CH}-$ ) proton from the iminopyrrolyl ligand appeared at $\delta 7.55 \mathrm{ppm}$, which is slightly high-field shifted

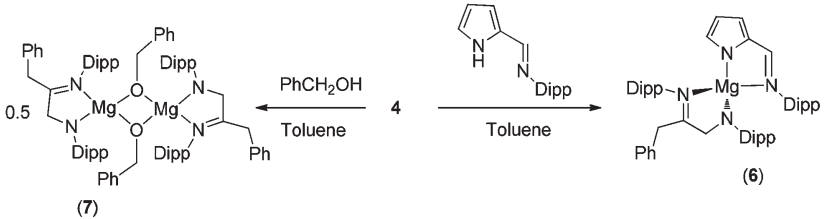

Scheme 5 Syntheses of magnesium complexes 6 and 7 . from the corresponding value $(7.87 \mathrm{ppm})$ in complex 5 . The singlet resonance at $\delta 4.36 \mathrm{ppm}$ can be assigned to benzylic protons of the benzylated DAD ligand and this value is in the same range $(3.32 \mathrm{ppm})$ as that of the corresponding value in complex 4. Two septets at $\delta 2.82$ and $2.73 \mathrm{ppm}$ were obtained for chemically non-equivalent four isopropyl $-\mathrm{CH}$ groups present in the benzylated DAD ligand. One additional septet at $\delta 3.10 \mathrm{ppm}$ was observed and can be assigned to two isopropyl $-\mathrm{CH}$ groups which can undergo free rotation around the $\mathrm{C}-\mathrm{N}$ bond present in the iminopyrrolyl ligand. Three doublets at $\delta 1.18,1.08$ and $0.89 \mathrm{ppm}$ with coupling constants of $6.4,6.0$ and $6.6 \mathrm{~Hz}$, respectively, were also observed for methyl protons of 2,6-diisopropylphenyl groups present in iminopyrrolyl and benzylated DAD ligands. The resonances in the ${ }^{13} \mathrm{C}\left\{{ }^{1} \mathrm{H}\right\}$ NMR spectra were in the expected regions.

Complex 6 crystallised in the monoclinic space group $P 2_{1} / c$, with four molecules in the unit cell. The details of structural parameters are given in Table TS1 in the ESI $\dagger$ and the solidstate structure of complex 6 is shown in Fig. 5. The central metal magnesium atom adopted a distorted tetrahedral geometry due to the coordination of one bidentate iminopyrrolyl ligand and one bidentate benzylated DAD ligand. Both ligands bonded to the magnesium atom via the amido nitrogen and imine nitrogen atoms. Thus, the coordination mode of $\sigma^{2}$ was observed for both ligands. The $\mathrm{Mg}-\mathrm{N}^{\mathrm{pyr}}$ bond distance of 2.036 (3) $\AA$ was in the range of $\mathrm{Mg}-\mathrm{N}^{\mathrm{DAD}}$ amido distance 1.974(3) $\AA$ but slightly shorter than the $\mathrm{Mg}-\mathrm{N}^{\mathrm{pyr}}$ distance $[2.157(4) \AA]$ observed in complex 5. The $\mathrm{Mg}-\mathrm{N}^{\text {imine }}$ distances $[\mathrm{Mg} 1-\mathrm{N} 2$ 2.150(3) $\AA$ and $\mathrm{Mg} 1-\mathrm{N} 32.136(3) \AA]$ were slightly shorter than the corresponding distances obtained in complex 5 . These slight differences in bonding can be attributed to more tightly bound tetrahedral magnesium compared to the loosely bound

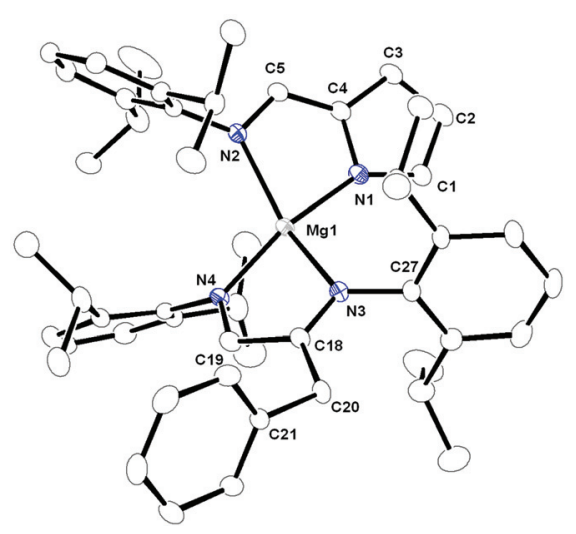

Fig. 5 Solid-state structure of complex 6 and ellipsoids are drawn to encompass $30 \%$ probability. Hydrogen atoms are omitted for clarity. Selected bond lengths [Å] and bond angles [']: Mg1-N1 2.036(3), Mg1N2 2.150(3), Mg1-N3 2.136(3), Mg1-N4 1.974(3), N3-C18 1.290(4), N3C27 1.447(5), N4-C19 1.437(5), C18-C19 1.482(5), C18-C20 1.519(5), N1-Mg1-N2 82.32(13), N1-Mg1-N3 100.19(13), N4-Mg1-N1 58.94(15), N4-Mg1-N3 81.63(12), N4-Mg1-N2 110.06(13), N3-Mg1-N2 139.50(13), C1-N1-Mg1 144.3(3), C4-N1-Mg1 110.1(2), C5-N2-Mg1 108.0(3), C18-N3-Mg1 110.6(2), C19-N4-Mg1 111.5(2), C27-N3-Mg1 127.4(2), C39-N4-Mg1 132.9(2), C18-N3-C27 122.0(3). 
square pyramidal magnesium with the respective ligands. The plane containing the magnesium five-membered metallacycle Mg1-N1-C4-C5-N2 was coplanar, with a pyrrole ring, but made a dihedral angle of $50.50^{\circ}$ with the plane containing a second five-membered magnesium metallacycle Mg1-N3-C18C19-N4. The C-N bond distances of N4-C19 1.437(5), C19-C18 1.482(5) and C18-N3 1.290(4) $\AA$ within the benzylated DAD moiety were similar to those present in complex 4 (1.442(12), $1.492(13)$ and $1.292(13)$ respectively).

The substitution of one benzylated DAD ligand in the magnesium atom by one pyrrolyl ligand can be explained as a result of higher stability of the anionic pyrrolyl ligand over the anionic benzylated DAD ligand. The solid-state structure is in accordance with the ${ }^{1} \mathrm{H}$ and ${ }^{13} \mathrm{C}\left\{{ }^{1} \mathrm{H}\right\}$ NMR spectra, as already discussed.

\section{Reaction with benzyl alcohol}

We observed that the $\mathrm{Mg}-\mathrm{N}^{\text {amido }}$ bonds in complex 4 were unstable towards acidic ligands such as $\mathrm{N}$-aryl iminopyrrole, resulting in the mixed ligand magnesium complex 6. To explore further the reactivity of the homoleptic complex $\mathbf{4}$, we treated it with benzyl alcohol in 1:1 molar ratio in toluene at ambient temperature to obtain another mixed ligand magnesium complex 7 in good yield (Scheme 4). Complex 7 shows one set of signals in the ${ }^{1} \mathrm{H}$ NMR spectra measured in $\mathrm{C}_{6} \mathrm{D}_{6}$. A singlet resonance at $\delta 4.42 \mathrm{ppm}$ was observed for two methylene protons $\left(-\mathrm{CH}_{2}\right)$ of the benzylated DAD ligand. Two other singlet resonances at $\delta 3.99$ and $3.38 \mathrm{ppm}$ can be assigned to two protons each of $-\mathrm{OCH}_{2} \mathrm{Ph}$ and $-\mathrm{CH}_{2} \mathrm{Ph}$ groups, respectively. Two septet signals at $\delta 2.92$ and $2.74 \mathrm{ppm}$ were observed due to resonances of protons present in chemically non-equivalent $-\mathrm{CH}$ groups of the benzylated DAD ligand. In addition, two doublets with coupling constants of 6.6 and $6.4 \mathrm{~Hz}$ at 1.15 and $1.00 \mathrm{ppm}$ were obtained due to the resonance of the

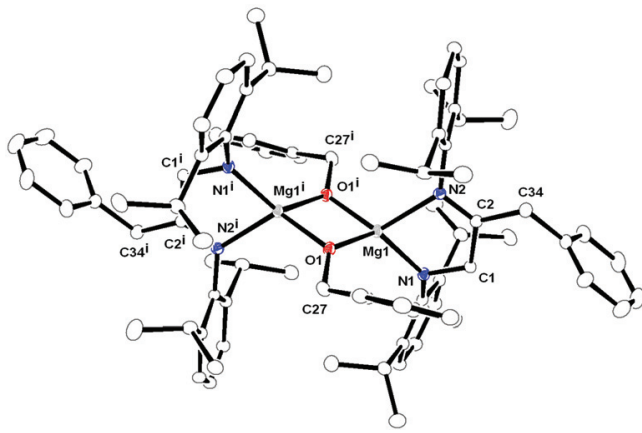

Fig. 6 Solid-state structure of complex 7 and ellipsoids are drawn to encompass $30 \%$ probability. Hydrogen atoms are omitted for clarity. Selected bond lengths [Å] and bond angles [ ${ }^{\circ}$ ]: Mg1-O1 1.9560(16), Mg1-O1' 1.9602(17), O1-Mg1' 1.9602(17), Mg1-N1 1.9788(19), Mg1-N2 2.1452(19), N1-C1 1.438(3), N2-C2 1.291(3), O1-C27 1.413(3), C1-C2 1.506(3), C(2)-C(34) 1.513(3), O(1)-C(27 1.413(3), O1-Mg1-O1' 84.53(7), O1-Mg1-N1 124.62(8), O1-Mg1-N1' 133.37(8), O1-Mg1-N2 117.76(7), O1'-Mg1-N2 117.70(7), N1-Mg1-N2 82.73(7), C1-N1-Mg1 111.17(13), C2-N2-Mg1 109.45(14), C27-O1-Mg1 134.31(14), C27-O1-Mg1 126.09(13), Mg1-O1-Mg1' 95.47(7), N1-C1-C2 114.70(17), N2-C2-C1 118.47(18), N2-C2-C34 123.29(19), C1-C2-C34 118.23(18). methyl protons present in the ligand. The ${ }^{13} \mathrm{C}\left\{{ }^{1} \mathrm{H}\right\}$ NMR spectra were also in the expected range and very similar to that of complex 4. The solid-state structure of complex 7 was established by single-crystal X-ray diffraction analysis (Fig. 6).

X-ray quality crystal of complex 7 was obtained from hot toluene. Complex 7 crystallised in the triclinic space group $P \overline{1}$, with one molecule of complex 7 and one toluene as a solvent in the unit cell. The details of its structural parameters are given in Table TS1 in the ESI $\dagger$ and the solid-state structure of complex 7 is shown in Fig. 6. The molecular structure revealed that the centro-symmetric magnesium complex 7 is dimeric in nature, through $\mu$ bridging of two benzyloxy $\left(-\mathrm{OCH}_{2} \mathrm{Ph}\right)$ groups towards two magnesium ions. The coordination polyhedron in complex 7 was formed by the chelation of one amido and one imine nitrogen atoms from the monoanionic $\left[\text { DippN }=\mathrm{C}\left(\mathrm{CH}_{2} \mathrm{Ph}\right)-\mathrm{CH}_{2} \mathrm{NDipp}\right]^{-}$ligand moiety and two bridging benzyloxy groups to adopt each magnesium geometry as a distorted tetrahedral. To the best of our knowledge, complex 7 is the first example of a magnesium complex having a [DippN $\left.=\mathrm{C}\left(\mathrm{CH}_{2} \mathrm{Ph}\right) \mathrm{CH}_{2} \mathrm{NDipp}\right]$ ligand as well as a benzyloxy ligand. Two kinds of $\mathrm{Mg}-\mathrm{N}$ distances [Mg1-N1 1.9788(19) $\AA$ and Mg-N2 2.1452(19) $\mathrm{A}$ ] revealed that each magnesium atom is asymmetrically attached to one amido nitrogen ( $\mathrm{N} 1$ and $\mathrm{N} 1^{\mathrm{i}}$ ) and one imine nitrogen ( $\mathrm{N} 2$ and $\mathrm{N} 2{ }^{\mathrm{i}}$ ) of the benzylated DAD ligand. The Mg-O distances [1.9560(16) and 1.9602(17) ^] were in the range of the reported $\mathrm{Mg}-\mathrm{O}$ distances in the literature $\left[(1.896(4) \AA]{ }^{22 a}\right.$ Thus, two magnesium metallacycles Mg1-N1$\mathrm{C} 1-\mathrm{C} 2-\mathrm{N} 2$ and $\mathrm{Mg} 1^{\mathrm{i}}-\mathrm{N} 1^{\mathrm{i}}-\mathrm{C} 1^{\mathrm{i}}-\mathrm{C} 2^{\mathrm{i}}-\mathrm{N} 2^{\mathrm{i}}$ along with a diamond core $\mathrm{Mg} 1-\mathrm{O} 1-\mathrm{Mg} 1^{\mathrm{i}}-\mathrm{O} 1^{\mathrm{i}}$ were observed in complex 7 due to ligation of two different ligand systems. Both metallacycles were not coplanar and magnesium ions lay $0.443 \AA$ above the mean plane containing N1, C1, C2 and N2 atoms, and $0.443 \AA$ down the plane containing $\mathrm{N} 1^{\mathrm{i}}-\mathrm{C} 1^{\mathrm{i}}-\mathrm{C} 2^{\mathrm{i}}-\mathrm{N} 2^{\mathrm{i}}$ atoms. The aromatic rings in benzyloxy groups were trans to each other to maintain the symmetry of the molecule.

\section{Experimental}

\section{General consideration}

All manipulations of air-sensitive materials were performed with the rigorous exclusion of oxygen and moisture in flamedried Schlenk-type glassware either on a dual manifold Schlenk line, interfaced to a high vacuum $\left(10^{-4}\right.$ torr $)$ line, or in an argon-filled M. Braun glove box. Toluene was distilled under nitrogen from $\mathrm{LiAlH}_{4}$ and stored in the glove box. ${ }^{1} \mathrm{H}$ NMR (400 MHz) and ${ }^{13} \mathrm{C}\left\{{ }^{1} \mathrm{H}\right\}$ NMR spectra were recorded on a Bruker Avance III-400 spectrometer. Bruker Alpha FT-IR was used for FT-IR measurements. Elemental analyses were performed on a Bruker Euro EA at the Indian Institute of Technology Hyderabad (IITH). Carbodiimides $(\mathrm{RN}=\mathrm{C}=\mathrm{NR} ; \mathrm{R}=\mathrm{Cy}$, ${ }^{\mathrm{i}} \mathrm{Pr},{ }^{t} \mathrm{Bu}$ ) were purchased from Sigma Aldrich and used as received. $\left[\mathrm{Mg}\left(\mathrm{CH}_{2} \mathrm{Ph}\right)_{2}\left(\mathrm{Et}_{2} \mathrm{O}\right)_{2}\right],{ }^{18} \mathrm{Dipp}_{2} \mathrm{DAD}^{32}$ and [ImpDipp-H $]^{33}$ were prepared according to a procedure described in the literature. The NMR solvent $\mathrm{C}_{6} \mathrm{D}_{6}$ was purchased from Sigma Aldrich and dried under $\mathrm{Na} / \mathrm{K}$ alloy prior to use. 
Preparation of $\left[\mathrm{Mg}\left(\mathrm{CH}_{2} \mathrm{Ph}\right)\left\{\mathrm{CyN}=\mathrm{C}\left(\mathrm{CH}_{2} \mathrm{Ph}\right) \mathrm{NCy}\right\}\right]_{2}$ (1). In a $50 \mathrm{~mL}$ dry Schlenk flask $N, N^{\prime}$-dicyclohexylcarbodiimide (DCC) (104 mg, $0.5 \mathrm{mmol})$ and $\left[\mathrm{Mg}\left(\mathrm{CH}_{2} \mathrm{Ph}\right)_{2}\left(\mathrm{Et}_{2} \mathrm{O}\right)_{2}\right](178 \mathrm{mg}$, $0.5 \mathrm{mmol}$ ) were mixed together in $1: 1$ ratio in $10 \mathrm{~mL}$ of toluene at ambient temperature and stirred for 12 hours at $60{ }^{\circ} \mathrm{C}$. The resulting clear solution was evaporated to dryness in vacuo and $2 \mathrm{~mL}$ of fresh toluene was introduced into the flask. The complex was recrystallised from hot toluene as colourless crystals. Yield $176 \mathrm{mg}(85 \%) .{ }^{1} \mathrm{H}$ NMR $(400 \mathrm{MHz}$, $\left.\mathrm{C}_{6} \mathrm{D}_{6}\right): \delta=7.28(\mathrm{~d}, 4 \mathrm{H}, J=7.5 \mathrm{~Hz}, \operatorname{ArH}), 7.15(\mathrm{t}, 4 \mathrm{H}, \mathrm{ArH}), 6.99$ (t, 2H, ArH), $3.70\left(\mathrm{~s}, 2 \mathrm{H}, \mathrm{Ph}-\mathrm{CH}_{2}\right), 3.21-3.14(\mathrm{~m}, 2 \mathrm{H}, \mathrm{CH}), 1.72$ (s, 2H, $\left.\mathrm{CH}_{2} \mathrm{Ph}\right), 1.70-1.67(\mathrm{~m}, 8 \mathrm{H}, \mathrm{Cy}-\mathrm{H}) 1.43-1.23(\mathrm{~m}, 12 \mathrm{H}$, $\mathrm{Cy}-H) \mathrm{ppm} ;{ }^{13} \mathrm{C}\left\{{ }^{1} \mathrm{H}\right\}$ NMR $\left(100 \mathrm{MHz}, \mathrm{C}_{6} \mathrm{D}_{6}\right): \delta=173.7(\mathrm{~N}=C-$ $\mathrm{N}), 137.7(\operatorname{ArC}), 128.8(\mathrm{ArC}), 126.4(\mathrm{ArC}), 67.1(\mathrm{Cy}-C-\mathrm{N}=\mathrm{C})$, $53.3(\mathrm{Cy}-\mathrm{C}-\mathrm{N}-\mathrm{C}), 37.5\left(\mathrm{Ph}-\mathrm{CH}_{2}\right), 26.4\left(\mathrm{Cy}-\mathrm{CH}_{2}\right), 25.9\left(\mathrm{Cy}-\mathrm{CH}_{2}\right)$, $25.3\left(\mathrm{Cy}-\mathrm{CH}_{2}\right)$ ppm. $\left(\mathrm{C}_{54} \mathrm{H}_{72} \mathrm{Mg}_{2} \mathrm{~N}_{4}\right)(825.79)$ Calc. C 78.54, H 8.79, N 6.78; found C 78.14 H 8.45, N 6.66.

Preparation of $\left[\mathrm{Mg}\left(\mathrm{CH}_{2} \mathbf{P h}\right)\left\{{ }^{\mathrm{i}} \mathrm{PrN}=\mathbf{C}\left(\mathrm{CH}_{2} \mathbf{P h}\right) \mathbf{N}^{\mathrm{i}} \mathrm{Pr}\right\}\right]_{2}$ (2). In a $50 \mathrm{~mL}$ dry Schlenk flask $N, N^{\prime}$-diisopropylcarbodiimide $(64 \mathrm{mg}$, $0.5 \mathrm{mmol})$ and $\left[\mathrm{Mg}\left(\mathrm{CH}_{2} \mathrm{Ph}\right)_{2}\left(\mathrm{Et}_{2} \mathrm{O}\right)_{2}\right](178 \mathrm{mg}, 0.5 \mathrm{mmol})$ were mixed together in $1: 1$ ratio in $10 \mathrm{~mL}$ of toluene at ambient temperature and the reaction mixture was stirred for 12 hours at $60{ }^{\circ} \mathrm{C}$. The resulting clear solution was evaporated to dryness in vacuo and $2 \mathrm{~mL}$ of fresh toluene was introduced into the flask. The complex was recrystallised from hot toluene as colourless crystals. Yield $135 \mathrm{mg}(80 \%) .{ }^{1} \mathrm{H}$ NMR $(400 \mathrm{MHz}$, $\left.\mathrm{C}_{6} \mathrm{D}_{6}\right): \delta=7.32(\mathrm{~d}, 4 \mathrm{H}, J=7.5 \mathrm{~Hz}, \mathrm{ArH}), 7.22(\mathrm{t}, 4 \mathrm{H}, \mathrm{ArH}), 7.08$ (t, 2H, ArH), 3.71 (s, 2H, Ph- $\mathrm{CH}_{2}$ ), 3.52-3.47 (m, 2H, CH), 3.40 (s, 2H, $\mathrm{CH}_{2}$ ), 1.89 (s, 2H, $\left.\mathrm{CH}_{2} \mathrm{Ph}\right), 1.13$ (d, 6H, $J=1.8 \mathrm{~Hz}, \mathrm{CH}_{3}$ ) $1.10\left(\mathrm{~m}, 6 \mathrm{H}, J=1.8 \mathrm{~Hz}, \mathrm{CH}_{3}\right) \mathrm{ppm} ;{ }^{13} \mathrm{C}\left\{{ }^{1} \mathrm{H}\right\} \mathrm{NMR}(100 \mathrm{MHz}$, $\left.\mathrm{C}_{6} \mathrm{D}_{6}\right): \delta=173.5(\mathrm{~N}=C-\mathrm{N}), 137.4(\operatorname{ArC}), 128.3(\operatorname{ArC}), 126.4$ $(\mathrm{ArC}), 67.1\left({ }^{\mathrm{i}} \mathrm{Pr}-C-\mathrm{N}=\mathrm{C}\right), 45.7\left({ }^{\mathrm{i}} \mathrm{Pr}-C-\mathrm{N}-\mathrm{C}\right), 31.2\left(\mathrm{Ph}-\mathrm{CH}_{2}\right), 26.9$ ( $\left.{ }^{\mathrm{i}} \mathrm{Pr}-\mathrm{C}\right), 25.5\left(\mathrm{CH}_{3}\right)$ ppm. $\left(\mathrm{C}_{42} \mathrm{H}_{56} \mathrm{Mg}_{2} \mathrm{~N}_{4}\right)$ (665.53) Calc. C 75.80, $\mathrm{H}$ 8.48, N 8.42; found C 75.36 H 8.13, N 8.22.

Preparation of $\left[\mathbf{M g}\left\{{ }^{t} \mathbf{B u N}=\mathbf{C}\left(\mathbf{C H}_{2} \mathbf{P h}\right) \mathbf{N}^{t} \mathbf{B u}\right\}_{2}\right]$ (3). In a $50 \mathrm{~mL}$ dry Schlenk flask $N, N^{\prime}$-di-tert-butylcarbodiimide (154 mg, $1 \mathrm{mmol})$ and $\left[\mathrm{Mg}\left(\mathrm{CH}_{2} \mathrm{Ph}\right)_{2}\left(\mathrm{Et}_{2} \mathrm{O}\right)_{2}\right](178 \mathrm{mg}, 0.5 \mathrm{mmol})$ were mixed together in 2:1 ratio in $10 \mathrm{~mL}$ of toluene at ambient temperature and stirred for 12 hours at $60{ }^{\circ} \mathrm{C}$. The resulting clear solution was evaporated in vacuo to dryness and $2 \mathrm{~mL}$ of toluene was introduced into the flask. The title complex was recrystallised from hot toluene as colourless crystals. Yield $210 \mathrm{mg}$ (81\%). ${ }^{1} \mathrm{H}$ NMR (400 MHz, $\left.\mathrm{C}_{6} \mathrm{D}_{6}\right): \delta=7.30$ (d, $4 \mathrm{H}, J=$ $7.4 \mathrm{~Hz}, \operatorname{ArH}), 7.19$ (t, 4H, ArH), 7.06 (t, 2H, ArH), $3.71(\mathrm{~s}, 4 \mathrm{H}$, $\mathrm{Ph}-\mathrm{CH}_{2}$ ), 1.01 (s, 36H, $\left.\mathrm{CH}_{3}\right) \mathrm{ppm} ;{ }^{13} \mathrm{C}\left\{{ }^{1} \mathrm{H}\right\}$ NMR $(100 \mathrm{MHz}$, $\left.\mathrm{C}_{6} \mathrm{D}_{6}\right): \delta=173.5(\mathrm{~N}=C-\mathrm{N}), 137.4(\operatorname{ArC}), 128.3(\operatorname{ArC}), 126.4$ $(\mathrm{ArC}), 62.3\left(\mathrm{CMe}_{3}\right), 29.8\left(\mathrm{CMe}_{3}\right)$ ppm. $\left(\mathrm{C}_{32} \mathrm{H}_{50} \mathrm{MgN}_{4}\right)(515.07)$ Calc. C 74.62, H 9.78, N 10.88; found C 74.39 H 9.53, N 10.41.

Preparation of $\left[\mathrm{Mg}\left\{\mathrm{DippN}=\mathrm{C}\left(\mathrm{CH}_{2} \mathrm{Ph}\right) \mathrm{CH}_{2} \mathbf{N D i p p}\right\}_{2}\right]$ (4). In a $50 \mathrm{~mL}$ dry Schlenk flask $N, N^{\prime}$-bis(2,6-diisopropylphenyl)-1,4diaza-butadiene(DAD) $(376 \mathrm{mg}, 1 \mathrm{mmol})$ and $\{\mathrm{Mg}$ $\left.\left(\mathrm{CH}_{2} \mathrm{Ph}\right)_{2}\left(\mathrm{Et}_{2} \mathrm{O}\right)_{2}\right\}(178 \mathrm{mg}, 0.5 \mathrm{mmol})$ were mixed together in $2: 1$ ratio in $10 \mathrm{~mL}$ of toluene at ambient temperature and stirred for 12 hours at room temperature. The resulting red solution was evaporated in vacuo to dryness and $2 \mathrm{~mL}$ of toluene was introduced into the flask. Complex $\mathbf{4}$ was recrystal- lised from hot toluene as red crystals. Yield $340 \mathrm{mg}(77 \%) .{ }^{1} \mathrm{H}$ NMR (400 MHz, $\mathrm{C}_{6} \mathrm{D}_{6}$ ): $\delta=7.19-7.09$ (m, 4H, ArH), 7.03-6.99 (m, 12H, ArH), 6.94-6.89 (m, 6H, ArH), $4.32\left(\mathrm{~s}, 4 \mathrm{H}, \mathrm{N}-\mathrm{CH}_{2}\right)$, 3.56 (sept, 4H, CH), 3.22 (s, 4H, Ph- $\mathrm{CH}_{2}$ ), 2.90 (sept, 4H, $\mathrm{CH}$ ), $1.23\left(\mathrm{~d}, 24 \mathrm{H}, J=6.8 \mathrm{~Hz}, \mathrm{CH}_{3}\right) 1.13\left(\mathrm{~d}, 24 \mathrm{H}, J=6.8 \mathrm{~Hz}, \mathrm{CH}_{3}\right)$ ppm; ${ }^{13} \mathrm{C}\left\{{ }^{1} \mathrm{H}\right\}$ NMR $\left(100 \mathrm{MHz}, \mathrm{C}_{6} \mathrm{D}_{6}\right): \delta=173.5(\mathrm{ArC}), 137.4$ $(\mathrm{ArC}), 128.3(\mathrm{ArC}), 126.4(\mathrm{ArC}), 67.1,45.7,31.2,26.9\left(\mathrm{CHMe}_{2}\right)$, 25.5 ppm $(\mathrm{CHMe} 2) \cdot\left(\mathrm{C}_{73} \mathrm{H}_{94} \mathrm{MgN}_{4}\right)$ (1051.86) Calc. C 83.36, $\mathrm{H}$ 9.01, N 5.33; found C 82.92 H 8.77, N 4.88.

Preparation of $\left[\mathrm{Mg}(\mathrm{ImpDipp})_{2}\left\{\mathrm{CyN}=\mathrm{C}\left(\mathrm{CH}_{2} \mathrm{Ph}\right) \mathrm{NHCy}\right\}\right]$ (5). In a $50 \mathrm{~mL}$ dry Schlenk flask complex 1 (206 mg, $0.5 \mathrm{mmol}$ ) and $\mathrm{N}$-aryl iminopyrrole [ImpDippH] $(248 \mathrm{mg}$, $1 \mathrm{mmol}$ ) were mixed together in $1: 2$ ratio in $10 \mathrm{~mL}$ of toluene at ambient temperature and stirred for 12 hours at $60{ }^{\circ} \mathrm{C}$. The resulting clear solution was evaporated to reduce the whole volume to $2 \mathrm{~mL}$. The complex was recrystallised from hot toluene as colourless crystals. Yield 305 (74\%). ${ }^{1} \mathrm{H}$ NMR $\left(400 \mathrm{MHz}, \mathrm{C}_{6} \mathrm{D}_{6}\right): \delta=7.91$ and $7.87(\mathrm{~s}, 2 \mathrm{H}, \mathrm{N}=\mathrm{CH}), 7.28-7.15$ (m, 11H, ArH), 7.07 (d, 2H, $J=6.6, \mathrm{Py}-H), 6.73(\mathrm{~m}, 2 \mathrm{H}, \mathrm{Py}-H)$, $6.15(\mathrm{~d}, 2 \mathrm{H}, J=6.6, \mathrm{Py}-H), 4.06(\mathrm{br}, 1 \mathrm{H}, \mathrm{NH}), 3.82-3.77(\mathrm{~m}, 1 \mathrm{H}$, $\mathrm{Cy}-\mathrm{CH}$ ), 3.48 (s, 2H, CH 3.34 (sept, 4H, CH), 3.04-2.98 (m, $1 \mathrm{H}, \mathrm{Cy}-\mathrm{CH}), 1.58-1.45\left(\mathrm{~m}, 12 \mathrm{H}, \mathrm{Cy}-\mathrm{CH}_{2}\right) 1.18(\mathrm{~d}, 24 \mathrm{H}, J=$ $\left.6.4 \mathrm{~Hz}, \mathrm{CH}_{3}\right), 0.80-0.75\left(\mathrm{~m}, 8 \mathrm{H}, \mathrm{Cy}-\mathrm{CH}_{2}\right) \mathrm{ppm} ;{ }^{13} \mathrm{C}\left\{{ }^{1} \mathrm{H}\right\} \mathrm{NMR}$ $\left(100 \mathrm{MHz}, \mathrm{C}_{6} \mathrm{D}_{6}\right): \delta=173.5(\mathrm{~N}=C-\mathrm{N}), 143.4(\operatorname{ImpN}=C), 140.7$ $(\mathrm{Ar}-C), 138.9(\mathrm{Ar}-C), 137.9(\mathrm{Ar}-C), 137.3(\mathrm{Ar}-C), 136.8(\mathrm{Ar}-C)$, 129.1 (Ar-C), $128.8(\mathrm{Ar}-C), 125.5(\mathrm{Py}-C), 125.4(\mathrm{Py}-C), 59.1(\mathrm{Cy}-$ $C-\mathrm{N}), 52.3(\mathrm{Cy}-\mathrm{C}-\mathrm{N}), 32.1\left(\mathrm{Ph}-\mathrm{CH}_{2}\right), 29.2(\mathrm{CH}), 28.9(\mathrm{CH}), 28.5$ $\left(\mathrm{CH}_{2}\right), 26.4\left(\mathrm{CH}_{2}\right), 25.4\left(\mathrm{CH}_{2}\right), 23.6\left(\mathrm{CH}_{2}\right), 22.1\left(\mathrm{CH}_{3}\right), 21.3$ $\left(\mathrm{CH}_{3}\right)$ ppm. $\left(\mathrm{C}_{54} \mathrm{H}_{70} \mathrm{MgN}_{6}\right)$ (827.48) Calc. C 78.38, H 8.53, N 10.16; found C 77.87 H 8.08, N 9.73.

Preparation of $\left[\mathrm{Mg}\left\{\mathrm{DippN}=\mathrm{C}\left(\mathrm{CH}_{2} \mathrm{Ph}\right) \mathrm{CH}_{2} \mathrm{NDipp}\right\}\right.$ (ImpDipp)] (6). In a $25 \mathrm{~mL}$ dry Schlenk flask magnesium complex 4 (240 mg, $0.25 \mathrm{mmol}$ ) and $N$-aryl iminopyrrole [ImpDippH] (63 mg, $0.25 \mathrm{mmol}$ ) were mixed together in 1:1 ratio in $10 \mathrm{~mL}$ of toluene at ambient temperature and stirred for 12 hours at room temperature. The resulting red solution was evaporated to dryness in vacuo and $2 \mathrm{~mL}$ of toluene was introduced into the flask. Complex 6 was recrystallised from hot toluene as yellow crystals. Yield $160 \mathrm{mg}$ (78\%). ${ }^{1} \mathrm{H}$ NMR $\left(400 \mathrm{MHz}, \mathrm{C}_{6} \mathrm{D}_{6}\right): \delta=7.55(\mathrm{~s}, 1 \mathrm{H}, \mathrm{N}=\mathrm{CH}), 7.08(\mathrm{~d}, 6 \mathrm{H}, J=6.4$ $\mathrm{Hz}, \mathrm{ArH}), 6.99-6.92(\mathrm{~m}, 10 \mathrm{H}, \mathrm{Py}-H$ and $\mathrm{Ar}-H), 6.78$ (t, H, Py$H$ ), 6.47 (d, $1 \mathrm{H}, J=6.6, \mathrm{Py}-H), 4.49$ (s, 2H, N-CH $H_{2}, 4.36(\mathrm{~s}, 2 \mathrm{H}$, Ph- $\mathrm{CH}_{2}$ ), 3.10 (sept, 2H, CH), 2.82 (sept, 2H, CH), 2.73 (sept, $2 \mathrm{H}, \mathrm{CH}), 1.18\left(\mathrm{~d}, 12 \mathrm{H}, J=6.4 \mathrm{~Hz}, \mathrm{CH}_{3}\right), 1.08(\mathrm{~d}, 12 \mathrm{H}, J=6.0 \mathrm{~Hz}$, $\left.\mathrm{CH}_{3}\right), 0.89\left(\mathrm{~d}, 12 \mathrm{H}, J=6.6 \mathrm{~Hz}, \mathrm{CH}_{3}\right) \mathrm{ppm} ;{ }^{13} \mathrm{C}\left\{{ }^{1} \mathrm{H}\right\} \mathrm{NMR}$ $\left(100 \mathrm{MHz}, \mathrm{C}_{6} \mathrm{D}_{6}\right): \delta=163.8\left(\mathrm{~N}=C-\mathrm{CH}_{2} \mathrm{Ph}\right), 153.6(\operatorname{ImpN}=C)$, $148.6(\operatorname{ImpN}=C), 138.0(\mathrm{Ar}-C), 136.8(\mathrm{Ar}-C), 135.0(\mathrm{Ar}-C)$, $129.5(\mathrm{Ar}-C), 128.8(\mathrm{Ar}-C), 127.3(\mathrm{Ar}-C), 126.8(\mathrm{Ar}-C), 125.9$ $(\mathrm{Ar}-C), 124.6(\mathrm{Py}-C), 124.3(\mathrm{Py}-C), 123.7$ (Py-C), $123.4(\mathrm{Py}-C)$, $64.9\left(\mathrm{~N}-\mathrm{CH}_{2}\right), 40.7\left(\mathrm{Ph}-\mathrm{CH}_{2}\right), 29.1(\mathrm{CH}), 28.9(\mathrm{CH}), 25.3\left(\mathrm{CH}_{3}\right)$, $25.0\left(\mathrm{CH}_{3}\right), 24.9\left(\mathrm{CH}_{3}\right), 24.6\left(\mathrm{CH}_{3}\right)$ ppm. $\left(\mathrm{C}_{50} \mathrm{H}_{64} \mathrm{MgN}_{4}\right)(745.36)$ Calc. C 80.57, H 8.65, N 7.52; found C 80.02 H 8.21, N 7.13.

Preparation of $\left[\mathrm{Mg}\left\{\right.\right.$ DippN $\left.=\mathbf{C}\left(\mathrm{CH}_{2} \mathrm{Ph}\right) \mathrm{CH}_{2} \mathrm{NDipp}\right\}$ $\left.\left(\mathbf{O C H}_{2} \mathbf{P h}\right)\right]_{2}$ (7). In a $25 \mathrm{~mL}$ dry Schlenk flask magnesium complex 4 (240 mg, $0.25 \mathrm{mmol}$ ) and benzyl alcohol $(0.025 \mathrm{~mL}$, $0.25 \mathrm{mmol}$ ) were mixed together in $1: 1$ ratio in $10 \mathrm{~mL}$ of 
toluene at ambient temperature and stirred for 12 hours at room temperature. The resulting red solution was evaporated to dryness and $2 \mathrm{~mL}$ of toluene was introduced into the flask. Complex 7 was recrystallised from hot toluene as yellow crystals. Yield $280 \mathrm{mg}$ (74\%). ${ }^{1} \mathrm{H}$ NMR (400 MHz, $\mathrm{C}_{6} \mathrm{D}_{6}$ ): 7.17-6.98 $(\mathrm{m}, 16 \mathrm{H}, \mathrm{Ar}-\mathrm{H}), 4.42\left(\mathrm{~s}, 2 \mathrm{H}, \mathrm{N}-\mathrm{CH}_{2}\right), 3.99\left(\mathrm{~s}, 2 \mathrm{H}, \mathrm{O}-\mathrm{CH}_{2}\right), 3.38$ (s, 2H, $\mathrm{PhCH}_{2}$ ), 2.92 (sept, 2H, CH), 2.74 (sept, 2H, CH), 1.15 (d, $12 \mathrm{H}, J=6.6 \mathrm{~Hz}, \mathrm{CH}_{3}$ ), 1.00 (d, $12 \mathrm{H}, J=6.4 \mathrm{~Hz}, \mathrm{CH}_{3}$ ) ppm; ${ }^{13} \mathrm{C}\left[{ }^{1} \mathrm{H}\right] \mathrm{NMR}\left(100 \mathrm{MHz}, \mathrm{C}_{6} \mathrm{D}_{6}\right): \delta 172.5(\mathrm{ArC}), 137.4(\mathrm{ArC}), 128.3$ $(\mathrm{ArC}), 126.4(\mathrm{ArC}), 64.7\left(\mathrm{O}-\mathrm{CH}_{2}\right), 45.7,31.2,26.9\left(C \mathrm{HMe}_{2}\right)$, 25.5 ppm $\left(\mathrm{CHMe}_{2}\right)$ ppm; $\left(\mathrm{C}_{94} \mathrm{H}_{116} \mathrm{Mg}_{2} \mathrm{~N}_{4} \mathrm{O}_{2}\right)$ (1382.5) Calc. C 81.66, H 8.46, N 4.05; found C 81.11 H 8.21, N 3.79.

\section{X-Ray crystallographic studies of complexes 1-7}

Single crystals of complexes 1-7 were grown from hot toluene under inert atmosphere. For complexes 1-7, a crystal of a suitable dimension was mounted on a CryoLoop (Hampton Research Corp.) with a layer of light mineral oil and placed in a nitrogen stream at 120(2) K. All measurements were made on a Rigaku RAXIS RAPID imaging plate area detector with graphite monochromated Mo-K $\alpha(0.71075 \AA)$ radiation. Crystal data and structure refinement parameters are summarised in Table TS1 in the ESI. $\dagger$ The structures were solved by direct methods (SIR92) ${ }^{34}$ and refined on $F^{2}$ by full-matrix leastsquares methods, using SHELXL-97. ${ }^{35}$ Non-hydrogen atoms were anisotropically refined. $\mathrm{H}$ atoms were included in the refinement at calculated positions riding on their carrier atoms. No restraint was made for any of the complexes. The function minimised was $\left[\sum \mathrm{w}\left(F_{\mathrm{o}}{ }^{2}-F_{\mathrm{c}}{ }^{2}\right)^{2}\right]\left(\mathrm{w}=1 /\left[\sigma^{2}\left(F_{\mathrm{o}}{ }^{2}\right)+\right.\right.$ $\left.\left.(a P)^{2}+b P\right]\right)$, where $P=\left(\operatorname{Max}\left({F_{\mathrm{o}}}^{2}, 0\right)+2{F_{\mathrm{c}}}^{2}\right) / 3$ with $\sigma^{2}\left(F_{\mathrm{o}}{ }^{2}\right)$ from counting statistics. The function $R_{1}$ and $\mathrm{w} R_{2}$ were $\left(\sum|| F_{\mathrm{o}} \mid-\right.$ $\left.\left|F_{\mathrm{c}}\right| \mid\right) / \sum\left|F_{\mathrm{o}}\right|$ and $\left[\sum \mathrm{w}\left(F_{\mathrm{o}}{ }^{2}-{F_{\mathrm{c}}}^{2}\right)^{2} / \sum\left(\mathrm{w} F_{\mathrm{o}}{ }^{4}\right)\right]^{1 / 2}$, respectively. ORTEP-3 program was used to draw the molecular structure. Crystallographic data (excluding structure factors) for the structures reported in this paper have been deposited at the Cambridge Crystallographic Data Centre as supplementary publication no. CCDC 1019669-1019675.

\section{Conclusion}

We have demonstrated the synthetic and structural details of a novel series of magnesium amidinato complexes where the amidinato moieties were obtained from the insertion of a magnesium-carbon bond into the carbon-nitrogen double bond of three different carbodiimides and 1,4-diaza-1,3-butadiene. In each case the proligand either carbodiimide or DAD was converted to a mono-anionic amidinato ligand, which coordinated to the magnesium ion through amido and imino nitrogen atoms to act as a bidentate ligand. In a further reaction with $N$-aryl iminopyrrole, the magnesium amidinato complexes $\mathbf{1}$ and $\mathbf{4}$ afforded another class of magnesium complexes, with newly generated amidinato and pyrrolyl ligands in the metal coordination spheres. Complex 4 also readily reacted with benzyl alcohol in a controlled manner, resulting in a hybrid magnesium complex with benzyloxy-
$\left(-\mathrm{OCH}_{2} \mathrm{Ph}\right)$ along with a benzylated DAD ligand in the coordination sphere.

\section{Acknowledgements}

This work was supported by the Council of Scientific and Industrial Research (CSIR) scheme no. 01(2530)/11/EMRI) and start-up grant from IIT Hyderabad. S.A. and A.H. thank CSIR, India and J.B. thanks the University Grant Commission (UGC), India for their PhD fellowships. We sincerely thank Prof. Kazushi Mashima and Dr Hayato Tsurugi, Osaka University for their generous support.

\section{Notes and references}

1 (a) V. C. R. Grignard, Acad. Sci., 1900, 130, 1322-1324; (b) V. C. R. Grignard, Ann. Chim., 1901, 24, 433-490;

(c) D. Seyferth, Organometallics, 2009, 28, 1598-1605.

2 (a) F. J. Bickelhaupt, Organomet. Chem., 1994, 475, 1-14; (b) M. Westerhausen, Angew. Chem., Int. Ed., 2001, 40, 2975-2977; (c) M. Westerhausen, M. Gärtner, R. Fischer, J. Langer, L. Yu and M. Reiher, Chem. - Eur. J., 2007, 13, 6292-6306.

3 Y. Sarazin, M. Schormann and M. Bochmann, Organometallics, 2004, 23, 3296-3302.

4 L. J. Sanchez-Barba, A. Garces, M. Fajardo, C. AlonsoMoreno, J. Fernandez-Baeza, A. Otero, A. Antinolo, J. Tejeda, A. Lara-Sanchez and M. L_opez-Solera, Organometallics, 2007, 26, 6403-6411.

5 Z.-X. Wang and C.-Y. Qi, Organometallics, 2007, 26, 22432251.

6 C. E. Holloway and M. Melnik, J. Organomet. Chem., 1994, 465, 1-63.

7 P. R. Markies, O. S. Akkerman, F. Bickelhaupt, W. J. J. Smeets and A. J. Spek, Adv. Organomet. Chem., 1991, 32, 147-226.

8 F. Bickelhaupt, in Grignard Reagents: New Developments, ed. H. G. Richey, Wiley, Chichester, UK, 2000, ch. 9, pp. 299-328.

9 M. Reinmuth, U. Wild, D. Rudolf, E. Kaifer, M. Enders, H. Wadepohl and H.-J. Himmel, Eur. J. Inorg. Chem., 2009, 4795-4808.

10 (a) P. J. Bailey, C. M. Dick, S. Fabre, S. Parsons and L. J. Yellowlees, Dalton Trans., 2006, 1602-1610; (b) P. J. Bailey, C. M. Dick, S. Fabre, S. Parsons and L. J. Yellowlees, Chem. Commun., 2005, 4563-4565.

11 For $\mathrm{AlMe}_{3}$-promoted alkyl migrations, see, for example: (a) R. Lechler, H.-D. Hausen and J. Weidlein, J. Organomet. Chem., 1989, 359, 1-12; (b) V. C. Gibson, C. Redshaw, A. J. P. White and D. J. Williams, J. Organomet. Chem., 1998, 550, 453-456; (c) B. Walfort, A. P. Leedham, C. A. Russell and D. Stalke, Inorg. Chem., 2001, 40, 56685674; (d) S. B. Cortright, J. N. Coalter-III, M. Pink and J. N. Johnston, Organometallics, 2004, 23, 5885-5888; 
(e) T. Chivers, M. C. Copsey and M. Parvez, Chem. Commun., 2004, 2818-2819; (f) Q. Knijnenburg, J. M. M. Smits and P. H. M. Budzelaar, Organometallics, 2006, 25, 1036-1046; (g) V. C. Gibson, C. Redshaw, G. A. Solan, A. J. P. White and D. J. Williams, Organometallics, 2007, 26, 5119-5123; (h) J. A. Olson, R. Boyd, J. W. Quail and S. R. Foley, Organometallics, 2008, 27, 53335338.

12 For $\mathrm{ZnMe}_{2}$-promoted alkyl migrations, see, for example: (a) U. Braun, B. B€ock, H. N€oth, I. Schwab, M. Schwartz, S. Weber and U. Wietelmann, Eur. J. Inorg. Chem., 2004, 3612-3628; (b) I. J. Blackmore, V. C. Gibson, P. B. Hitchcock, C. W. Rees, D. J. Williams and A. J. P. White, J. Am. Chem. Soc., 2005, 127, 6012-6020; (c) I. L. Fedushkin, A. N. Tishkina, G. K. Fukin, M. Hummert and H. Schumann, Eur. J. Inorg. Chem., 2008, 483-489.

13 For group 3-promoted alkyl migrations, see, for example: (a) M. Zimmermann, K. W. T€ornroos and R. Anwander, Angew. Chem., Int. Ed., 2007, 46, 3126-3130; (b) H. Kaneko, H. Tsurugi, T. K. Panda and K. Mashima, Organometallics, 2010, 29, 3463-3466.

14 For group 4 metal-promoted diimine alkylation, see: (a) K. Mashima, R. Ohnishi, T. Yamagata and H. Tsurugi, Chem. Lett., 2007, 36, 1420-1421; (b) R. E. Murray, U.S. Patent 6,096,676, Union Carbide Corp., 2000; (c) P. De Waele, B. A. Jazdzewski, J. Klosin, R. E. Murray, C. N. Theriault, P. C. Vosejpka and J. L. Petersen, Organometallics, 2007, 26, 3896-3899; (d) H. Tsurugi, R. Ohnishi, H. Kaneko, T. K. Panda and K. Mashima, Organometallics, 2009, 28, 680-687; (e) H. Tsurugi, K. Yamamoto and K. Mashima, J. Am. Chem. Soc., 2011, 133, 732-735.

15 (a) J. L. Atwood and G. D. Stucky, J. Am. Chem. Soc., 1969, 91, 2538-2543; K. Liebigs, Ann. Chem., 1957, 605, 93-97 (b) O. Michel, C. Meermann, K. W. Törnroos and R. Anwander, Organometallics, 2009, 28, 4783-4790.

16 O. Michel, K. Yamamoto, H. Tsurugi, C.-M. Mössmer, K. W. Törnroos, K. Mashima and R. Anwander, Organometallics, 2011, 30, 3818-3825.

17 T. K. Panda, H. Tsurugi, K. Pal, H. Kaneko and K. Mashima, Organometallics, 2010, 29, 34-37.

18 P. J. Bailey, R. A. Coxall, C. M. Dick, S. Fabre, L. C. Henderson, C. Herber, S. T. Liddle, D. L. Gonzalez, A. Parkin and S. Parsons, Chem. - Eur. J., 2003, 9, 48204828.

19 (a) R. J. Wehmschulte and P. P. Power, Organometallics, 1995, 14, 3264-3267; (b) S. S. Al-Juaid, C. Eaborn, P. B. Hitchcock, C. A. McGeary and J. D. Smith, Chem. Commun., 1989, 273-274; (c) P. B. Hitchcock, J. A. K. Howard, M. F. Lappert, W. P. Leung and S. A. Mason, Chem. Commun., 1990, 847-849; (d) K. B. Starowieyski, J. Lewinski, R. Wozniak, J. Lipkowski and A. Chrost, Organometallics, 2003, 22, 2458-2463.

20 (a) M-Dar Li, C-Cheng Chang, Y. Wang and G.-H. Lee, Organometallics, 1996, 15, 2571-2574; (b) A. Xia, M. J. Heeg and C. H. Winter, Organometallics, 2002, 21, 4718-4725; (c) H. Hao, S. Bhandari, Y. Ding, H. W. Roesky, J. Magull, H. G. Schmidt, M. Noltemeyer and C. Cui, Eur. J. Inorg. Chem., 2002, 1060-1065; (d) Y. Matsuo, H. Tsurugi, T. Yamagata and K. Mashima, Bull. Chem. Soc. Jpn., 2003, 76, 1965-1968; (e) A. Xia, H. M. El-Kaderi, M. J. Heeg and C. H. Winter, J. Organomet. Chem., 2003, 682, 224-232; $(f)$ T. K. Panda, K. Yamamoto, K. Yamamoto, H. Kaneko, Y. Yang, H. Tsurugi and K. Mashima, Organometallics, 2012, 31, 2268-2274; $(g)$ A. J. Blake, W. Lewis and D. L. Kays, Dalton Trans., 2014, 43, 4838-4846; (h) M. Westerhausen and H.-D. Hausen, Z. Anorg. Allg. Chem., 1992, 615, 27-34.

21 (a) R. T. Boeré, M. L. Colew and P. C. Junk, New J. Chem., 2005, 29, 128-134; (b) G. J. Moxey, F. Ortu, L. G. Sidley, H. N. Strandberg, T. Chivers, M. C. Copsey, C. Fedorchuk, M. Parvez and M. Stubbs, Organometallics, 2005, 24, 19191928; (c) M. Lin, W. Liu, Z. Chen, L. Yang, H. Pei, J. Wu, X. Wan, T. Lei and Y. Li, RSC Adv., 2012, 2, 3451-3457; (d) B. Liu, T. Roisnel, J.-F. Carpentier and Y. Sarazin, Angew. Chem., Int. Ed., 2012, 51, 4943-4946; (e) P. L. Arnold, I. S. Edworthy, C. D. Carmichael, A. J. Blake and C. Wilson, Dalton Trans., 2008, 3739-3748; (f) B. M. Day, N. E. Mansfield, M. P. Coles and P. B. Hitchcock, Chem. Commun., 2011, 47, 4995-4997; (g) L.-F. Hsueh, N.-T. Chuang, C.-Y. Lee, A. Datta, J.-H. Huang and T.-Y. Lee, Eur. J. Inorg. Chem., 2011, 5530-5537; (h) J.-C. Buffet, J. P. Davin, T. P. Spaniol and J. Okuda, New J. Chem., 2011, 35, 2253-2257; (i) M. H. Chisholm, J. C. Gallucci and K. Phomphrai, Inorg. Chem., 2005, 44, 8004-8010; (j) L. Wang and H. Ma, Macromolecules, 2010, 43, 65356537; (k) X. Xu, Y. Chen, G. Zou, Z. Ma and G. Li, J. Organomet. Chem., 2010, 695, 1155-1162.

22 (a) X. Zhang, T. J. Emge and K. C. Hultzsch, Angew. Chem., Int. Ed., 2012, 51, 394-398.

23 (a) J. Scholz, M. Dlikan, D. Ströhl, A. Dietrich, H. Schumann and K.-H. Thiele, Chem. Ber., 1990, 123, 2279-2285; (b) J. Scholz, A. Dietrich, H. Schumann and K.-H. Thiele, Chem. Ber., 1991, 124, 1035-1039; (c) J. Scholz, B. Richter, R. Goddard and C. Krüger, Chem. Ber., 1993, 126, 57-61; (d) B. Richter, J. Scholz, B. Neumüller, R. Weimann and H. Schumann, Z. Anorg. Allg. Chem., 1995, 621, 365-372; (e) H. Görls, B. Neumüller, A. Scholz and J. Scholz, Angew. Chem., Int. Ed. Engl., 1995, 34, 673-676.

24 (a) K. Vrieze, J. Organomet. Chem., 1986, 300, 307-326; (b) H. Bock and H. tom Dieck, Chem. Ber., 1967, 100, 228246.

25 (a) I. L. Fedushkin, N. M. Khvoinova, A. A. Skatova and G. K. Fukin, Angew. Chem., Int. Ed., 2003, 42, 5223-5226; (b) I. L. Fedushkin, A. A. Skatova, V. K. Cherkasov, V. A. Chudakova, S. Dechert, M. Hummert and H. Schumann, Chem. - Eur. J., 2003, 9, 5778-5783; (c) I. L. Fedushkin, A. A. Skatova, M. Hummert and H. Schumann, Eur. J. Inorg. Chem., 2005, 1601-1608; (d) I. L. Fedushkin, A. A. Skatova, G. K. Fukin, M. Hummert and H. Schumann, Eur. J. Inorg. Chem., 2005, 2332-2338; 
(e) I. L. Fedushkin, A. N. Lukoyanov, M. Hummert and H. Schumann, Z. Anorg. Allg. Chem., 2008, 634, 357-361; (f) Y. Liu, P. Yang, J. Yu, X.-J. Yang, J. D. Zhang, Z. Chen, H. F. Schaefer and B. Wu, Organometallics, 2008, 27, 58305835; ( $g$ ) S. Anga, K. Naktode, H. Adimulam and T. K. Panda, Dalton Trans., 2014, 43, 14876-14888.

26 (a) A. Galindo, A. Ienco and C. Mealli, New J. Chem., 2000, 24, 73-75; (b) P. J. Daff, M. Etienne, B. Donnadieu, S. Z. Knottenbelt and J. E. McGrady, J. Am. Chem. Soc., 2002, 124, 3818-3819; (c) M. Ghosh, S. Sproules, T. Weyhermüller and K. Wieghardt, Inorg. Chem., 2008, 47, 59635970; (d) M. Ghosh, T. Weyhermüller and K. Wieghardt, Dalton Trans., 2008, 5149-5151.

27 (a) K. Mashima, Y. Matsuo and K. Tani, Chem. Lett., 1997, 767-768; (b) K. Mashima, Y. Matsuo and K. Tani, Organometallics, 1999, 18, 1471-1481; (c) Y. Matsuo, K. Mashima and K. Tani, Angew. Chem., Int. Ed., 2001, 40, 960-962; (d) T. K. Panda, H. Kaneko, O. Michel, H. Tsurugi, K. Pal, K. W. Törnroos, R. Anwander and K. Mashima, Organometallics, 2012, 31, 3178-3184; (e) T. K. Panda, H. Kaneko, K. Pal, H. Tsurugi and K. Mashima, Organometallics, 2010, 29, 2610-2615; (f) S. Anga, R. K. Kottalanka, T. Pal and T. K. Panda, J. Mol. Struct., 2013, 1040, 129-138.

28 (a) A. A. Trifonov, E. N. Kirillov, S. Dechert, H. Schumann and M. N. Bochkarev, Eur. J. Inorg. Chem., 2001, 2509-2514; (b) A. A. Trifonov, Y. A. Kurskii, M. N. Bochkarev, S. Muehle, S. Dechert and H. Schumann, Russ. Chem. Bull., 2003, 52, 601-606; (c) A. A. Trifonov, E. A. Fedorova, V. N. Ikorskii, S. Dechert, H. Schumann and M. N. Bochkarev, Eur. J. Inorg. Chem., 2005, 2812-2818; (d) P. Cui, Y. Chen, G. Wang, G. Li and W. Xia, Organometallics, 2008, 27, 4013-4016. For lanthanide complexes having $\mu$-dianionic DAD ligands: (e) A. A. Trifonov, L. N. Zakharov, M. N. Bochkarev and Y. T. Struchkov, Russ. Chem. Bull, 1994, 43, 148-151; (f) J. Scholz, H. Görls, H. Schumann and R. Weimann, Organometallics, 2001, 20, 4394-4402.

29 (a) F. S. Mair, R. Manning, R. G. Pritchard and J. E. Warren, Chem. Commun., 2001, 1136-1137; (b) R. J. Baker, R. D. Farley, C. Jones, M. Kloth and D. M. Murphy, J. Chem. Soc., Dalton Trans., 2002, 3844-3850; (c) R. J. Baker, C. Jones and D. M. Murphy, Chem. Commun., 2005, 13391341; (d) X.-J. Yang, J. Yu, Y. Liu, Y. Xie, H. F. Schaefer, Y. Liang and B. Wu, Chem. Commun., 2007, 2363-2365; (e) C. Jones, A. Stasch and W. D. Woodul, Chem. Commun., 2009, 113-115.

30 Acenaphthene-based DAD complexes: (a) I. L. Fedushkin, A. A. Skatova, V. A. Chudakova, N. M. Khvoinova,
A. Y. Baurin, S. Dechert, M. Hummert and H. Schumann, Organometallics, 2004, 23, 3714-3718; (b) I. L. Feduchkin, N. M. Khvoinova, A. Y. Baurin, G. K. Fukin, V. K. Cherkasov and M. P. Bubnov, Inorg. Chem., 2004, 43, 7807-7815; (c) I. L. Fedushkin, V. A. Chudakova, A. A. Skatova, N. M. Khvoinova, Y. A. Kurskii, T. A. Glukhova, G. K. Fukin, S. Dechert, M. Hummert and H. Schumann, Z. Anorg. Allg. Chem., 2004, 630, 501-507; (d) I. L. Fedushkin, V.A. Chudakova, A. A. Skatova and G. K. Fukin, Heteroat. Chem., 2005, 16, 663-669; (e) H. Schumann, M. Hummert, A. N. Lukoyanov and I. L. Fedushkin, Organometallics, 2005, 24, 3891-3896; (f) A. N. Lukoyanov, I. L. Feduchkin, H. Schumann and M. Hummert, Z. Anorg. Allg. Chem., 2006, 632, 1471-1476; (g) I. L. Fedushkin, V. M. Makarov, E. C. E. Rosenthal and G. K. Fukin, Eur. J. Inorg. Chem., 2006, 827-832; (h) I. L. Fedushkin, M. Hummert and H. Schumann, Eur. J. Inorg. Chem., 2006, 3266-3273; (i) H. Schumann, M. Hummert, A. N. Lukoyanov and I. L. Fedushkin, Chem. - Eur. J., 2007, 13, 4216-4222; (j) I. L. Feduchkin, A. A. Skatova, O. V. Eremenko, M. Hummert and H. Schumann, Z. Anorg. Allg. Chem., 2007, 633, 1739-1742; ( $k$ ) I. L. Fedushkin, A. N. Tishkina, G. K. Fukin, M. Hummert and H. Schumann, Eur. J. Inorg. Chem., 2008, 483-489; (l) I. L. Feduchkin, A. G. Morozov, M. Hummert and H. Schumann, Eur. J. Inorg. Chem., 2008, 1584-1588; $(m)$ I. L. Fedushkin, A. S. Nikipelov, A. A. Skatova, O. V. Maslova, A. N. Lukoyanov, G. K. Fukin and A. V. Cherkasov, Eur. J. Inorg. Chem., 2009, 3742-3749; (n) I. L. Fedushkin, A. G. Morozov, V. A. Chudakova, G. K. Fukin and V. K. Cherkasov, Eur. J. Inorg. Chem., 2009, 4995-5003.

31 (a) R. K. Kottalanka, A. Harinath, J. Bhattacharjee, H. V. Babu and T. K. Panda, Dalton Trans., 2014, 43, 87578766; (b) R. K. Kottalanka, K. Naktode, S. Anga, H. P. Nayek and T. K. Panda, Dalton Trans., 2013, 42, 4947-4956.

32 (a) J. M. Kliegman and R. K. Barnes, Tetrahedron, 1970, 26, 2555-2560; (b) J. M. Kliegman and R. K. Barnes, J. Org. Chem., 1970, 35, 3140-3143; (c) H. A. Zhong, J. A. Labinger and J. E. Bercaw, J. Am. Chem. Soc., 2002, 124, 137801399.

33 Y. Matsuo, K. Mashima and K. Tani, Chem. Lett., 2000, 29, 1114-1115.

34 A. Altomare, M. C. Burla, G. Camalli, G. Cascarano, C. Giacovazzo, A. Gualiardi and G. Polidori, J. Appl. Crystallogr., 1994, 27, 435.

35 G. M. Sheldrick, Acta Crystallogr., Sect. A: Fundam. Crystallogr., 2008, 64, 112-122. 